\title{
Mexican immigration, occupational clustering, and the local labor market adjustment of African-American workers
}

\author{
Maude Toussaint-Comeau
}

\author{
Correspondence: \\ maude.toussaint@chi.frb.org \\ Federal Reserve Bank of Chicago, \\ 230 South LaSalle, Chicago, IL \\ 60604, USA
}

\begin{abstract}
Since the 1970s, economic restructuring and shifts in industries have morphed the occupational path of workers, curbing socioeconomic mobility for many-wages of African-American workers which have trended upward in the 1960s and 1970s started stalling beginning in the 1980s. As Hispanic/Mexican immigrants were being absorbed in various industry sectors, researchers have questioned whether unfavorable trends in African-American wages and employment outcomes are tied to Mexican immigration. This paper examines the effect of Mexican immigrants on wages for African-Americans using various estimation methods and finds consistent negative estimates, pointing to an inverse relationship between Mexican immigrants and wages for African-Americans, which is consistent with crowding out and substitution effects. However, in addition, analyses also show that a heavier source of depression of wages for African-Americans stems not just from immigration. In fact, in some ways, occupation clustering and specialization of Mexican immigrants mitigates impact of immigration on African-Americans on a whole range of low-skill occupations. But, all else equal, there appears rather to be a tendency for African-Americans to face an even greater "wage penalty" in more predominantly black occupations. The findings suggest that the interplay of immigration policy and workforce development policies and initiatives should be better understood as part of the conversation to redress factors preventing occupational and wage mobility of disadvantaged minority groups in the labor force.
\end{abstract}

\section{JEL Classification: J61, J62}

Keywords: Immigration, Wages, Occupation

\section{Introduction}

Wages and occupation status are important elements of the labor market adjustments and socioeconomic mobility of individuals. Many workers disproportionately among African-Americans and Mexican/Hispanic immigrants have seen diminished wage mobility and occupation advancements, which have reinforced inequality in the country (Von Lockette and Spriggs 2015). This paper explores the types of jobs held by Mexican immigrants and African-Americans and examines their implications on labor market adjustments and wage mobility prospects of the two groups.

Since the 1970s and early 1980s, the USA has undergone a profound transformation in its industrial structure, moving from a middle-wage, goods-producing manufacturing

(c) 2016 Toussaint-Comeau. Open Access This article is distributed under the terms of the Creative Commons Attribution 4.0 International License (http://creativecommons.org/licenses/by/4.0/), which permits unrestricted use, distribution, and reproduction in any medium, provided you give appropriate credit to the original author(s) and the source, provide a link to the Creative Commons license, and indicate if changes were made. 
economy toward a service-producing economy. These developments have received considerable attention among researchers who have viewed them as leading to a growing polarization of job opportunities-low-wage service jobs and high-wage professional service jobs (Bluestone and Harrison 1982; Harrison and Bluestone 1988; Lawrence 1984; Kosters and Ross 1987; Adams et al. 1991; Morris et al. 1994). Concomitant increasing monetary returns to education led to expanded employment opportunities in white-collar and professional jobs for the educated domestic workforce. Globalization, increased deregulation, and market liberalization have created a stauncher competitive environment and increased the need for firms to adopt costand wage-cutting strategies (OECD 2002). These developments have been fueled with increased labor supply arising from international migration of low-skill migrants, which created added pressure on wages for low-skill workers in the USA (Orrenius and Zavodny 2003).

During the 1990s, the number of Mexican immigrants living in the USA rose by more than five million. By the 2000 Census, Mexican immigrants made up more than $4 \%$ of the working-age population, close to twice more than the proportion a decade earlier. By 2003, Mexican immigration to the USA accounted for $28.3 \%$ of all foreignborn inhabitants of the country. Mexican immigrants constitute a sizable and growing segment of the US labor force, accounting for over 1 million of 2.5 million new jobs created in 2004 (Kochhar 2005).

One of the salient features of Mexican immigrants is the high degree of occupational clustering in low-waged and less-skilled occupations (i.e., in terms of educational requirement). For example, in 2003, recent Mexican immigrants who arrived in the previous 5 years constituted 1 to $5 \%$ of the labor force in their metropolitan receiving areas, yet they made up $29 \%$ of workers in certain occupations (Catanzarite 2003). Over the 1990s and 2000s, Mexican immigrants experienced strong gains in the (low-waged) service sector, including food preparation and serving, cleaning, and personal care, as well as in production, extraction, and farming occupations, while the US-born (native) workers' participation either declined or remained relatively lower in those occupations (Toussaint-Comeau et al. 2005).

The concentration of Mexican immigrants in certain occupations/industries has catalyzed a research and policy debate about whether they substitute natives in production. Does their concentration in certain occupations lead to pressures in wages for other low-skilled workers-particularly African-American workers? Or, does the pervasive pattern of concentration in specific occupational niche indicative of Mexicans filling jobs that are not necessarily chosen by US-born workers, at least during the prosperous 1990s? The size of the Mexican labor force and its potential role in affecting the overall wage structure suggest that it is important to have a better understanding of the nature of the relation between the Mexican immigrant workers and labor market outcomes of US-born counterparts.

The increase in Mexican immigrants in the labor force coincides with several specific trends in the labor market experiences of African-Americans, which begs question regarding its impact on this group in particular. Whereas Mexican immigrants had tended to be concentrated in relatively few cities, over the 1990s, they became increasingly dispersed, moving to cities like Atlanta that have had traditionally a large African-American population (Card 2005). In 2000, the employment rate of African-American men (fraction 
of weeks worked during a year) fell to $67.9 \%$ compared to $74.9 \%$ in 1960 (Borjas et al. 2008). Wages of African-Americans, which have been apparently trended toward converging with that of Whites in the 1960s and the 1970s, stalled beginning in the 1980s (Neal 2005; Amitabh 2000). Can these labor market trends experienced by African-Americans be attributed to Mexican immigration?

A number of studies have been concerned with examining the effect of immigration on African-Americans, guided by the notion that inflows of immigrants could presumably affect this group in particular (e.g., Altonji and Card 1991; LaLonde and Topel 1991; Borjas et al. 2008). These studies have found small or negligible effects. By contrast, Borjas et al. (2006) analyzed the effect of immigrants on African-Americans and found that as a disproportionate number of immigrants increase the supply of workers in some skill categories, the wages of black (African-American) workers tend to fall, by up to $4 \%$ for low skilled. Some studies have been concerned with the specific impact of Mexican immigration. Borjas and Katz (2005) find that Mexican immigration lowers wages of native high school dropouts by 4 to $8 \%$.

These previous studies have looked at either the effect of Mexicans on natives in general or the effect of immigration in general on African-Americans. In this paper, we focus on two groups-Mexican immigrants and African-Americans. We examine a much less researched aspect of the wage determination process-the role of occupational clustering or segregation and ethnic language networks in the wage determination process of a US-born minority worker group. Starting with the underlying notion that Mexican immigrants and African-American workers may not be doing the same jobs, we ask whether the tendency to be "specialized" or be segregated in distinct occupations with certain characteristics (manual relative to language communication skills requirements) mitigates the effect of Mexican immigrants on wages of African-American workers.

The methodological approach of this paper consists of conducting empirical analyses of the wage determination process in which we compare ordinary least squares (OLS) and occupation fixed-effects OLS estimates, with two-stage instrumental variable (IV) model estimates, in an attempt to correct for endogeneity of occupation composition. We innovate in this paper with the use of instruments which proxy for unobservable factors which relate to manual/language communication skills network effects, using a two-stage residual inclusion (2SRI) method, as well as using an instrument capturing previous labor supply shocks or occupation inflow from "new" Mexican immigrant cohorts, which we believe influence the choice of Mexican immigrants in distinct occupations, independent of compensating wage differences. To further explore how binding Mexican immigrants' impact really is on African-Americans, we also conduct complementary empirical experiments which explore further the effect of Mexican immigrants on wage adjustments for African-Americans, in the context of local labor markets with occupation segmentation and segregation, using a two-stage least-squares model with location selection.

We make use of several combined datasets from the Public Use Micro Statistics (PUMS), $5 \%$ sample from the US Census, which allow us to exploit variations across more than 475 detailed occupations by industry categories across time. We find that consistent with previous researches, there is an inverse relationship between an increase of Mexican immigrants in an occupation/industry and wages of 
African-Americans, suggestive of a potential for crowding out effect and substitution effect. The relevant relation between wages of African-Americans and Mexican immigrants appears not limited to the unskilled sectors. We find that Mexican immigrants have an impact on wages of workers in occupations in semi-skilled range (in which the average African-American workers have a high school diploma). At very high skill occupation range (those in which the average African-American workers have a college education), the lack of the presence of Mexican immigrants in those occupations corresponds to higher wages, suggestive of more complementarity in the production process among more-educated workers.

One of the more puzzling effects is that we find that in spite of the high concentration of Mexican immigrants in occupation ranges in which we find African-Americans that have very low education (less than high school-level education or are high school dropouts), there is no significant effect of Mexican immigrants on wages of African-Americans as a group in this education category. Following a formal model of occupation segmentation, we confirm that there is stronger pressure on wages of African-Americans in the more integrated occupations than there is in occupations with a strong Hispanic/Mexican immigrant niche. In other words, African-Americans compete, to a lesser degree, in "Hispanic/Mexican occupations", while the more relevant "competition" between African-Americans and Hispanic/Mexican immigrants may be in more integrated, semi-skilled occupations. In addition, we assess the effect on wages of African-Americans being clustered in certain occupations themselves. The result of this exercise shows, all else equal, that there appears to be a tendency for African-Americans to face a greater "wage penalty" or lower returns in predominantly black occupations, even after controlling for a number of characteristics.

The remainder of the paper is organized as follows: The next section provides a brief review of two strings of literature-a sociology literature that explains the process of immigrant/ethnic clustering in distinct occupations, as driven by ethnic/language networks, and an economic literature that purports to the effect of immigrants on wages of natives, as a backdrop to the empirical strategy taken in this paper. Section 3 describes the estimation procedure for the empirical analysis. Section 4 presents the data and the results of the empirical analysis. The penultimate sections discuss the economic significance of the result and additional considerations of local labor markets within states and metropolitan areas. The final section summarizes the paper and notes the implications of the findings.

\section{Theoretical conceptual background}

\subsection{Emergence of occupational clustering}

There is agreement that occupation segregation is present, but there is no single explanation as to its causes. The clustering of immigrants in distinct locations and occupations has risen from a host of circumstances. Immigrants concentrate in distinctive locations which were historically traditional ports of entries in the USA, reinforced by family-reunification-based immigration policy. Also, a large literature (from the sociology field, especially) speaks of the tendency by immigrants to concentrate spatially in neighborhoods or ethnic enclaves and to develop ethnic economies which take advantage of ethnic network or ethnic capital. This literature 
provides insights into the process of "ethnic niche" formation, which suggests how immigrants become concentrated in certain occupation niche. Ethnic occupation niche can arise from practices of recruitment of new workers through the networks of current workers (Park 2004; Mouw 2003; Waldinger and Der-Martirosian 2001; Gallo and Bailey 1996). For example, the concentration of Mexicans in farming is partly a result of the practices of recruitment of workers from the migrant labor pool and immigration policy such as the Bracero Program (Betancur et al. 1993). Occupation clustering can also rise from the process of "ethnic succession" in the job market. This process can be partly a result of the dynamics of "residential segregation", whereby natives exit certain sectors as immigrants enter them, a phenomenon that has been documented in New York City between Whites and Cubans (Waldinger 1996; Wright and Elllis 1996).

Occupations tend to be heterogeneous in their use of language. Hellerstein and Neumark (2004) find that occupations are strongly segregated along the line of language ability and that segregation by language explains one third of Hispanic-white segregation in the workplace. Occupational segregation by immigrants is reinforced with a common language and shared information about employment opportunities through ethnic networks. This is evidenced by the fact that some immigrants tend to cluster in relatively few occupations. For example, in occupations that have traditionally been held by immigrants, employers are less likely to screen out those who have a lack of the English knowledge (Kossoudji 1998). According to the sociological perspective, occupational segregation, if pronounced enough, can result into a type of "segmented" labor market, whereby native workers could be insulated from a direct impact of immigrants. Hamermesh (1993) finds that the cross-elasticity between immigrants and natives (the degree of complementarity or substitution between immigrants in a set of occupations and natives in another) is very small, suggesting that labor market may be divided along the sector defined by immigrant status/language skill.

\subsection{Impact of immigrants on wages of natives: the simple framework}

Economic theory also provides some explanations for occupation segregation and its potential effect on wages. A group may be disproportionately concentrated in occupations with low earnings due to market discrimination or due to a self-sorting mechanism (e.g., as it may be the case for women with children). Either way, if employers exclude a group from the better-pay occupations, or if the group self-selects into the low-pay occupations, then the group would be crowded in those occupations, compressing wages in there furthermore.

A large economic literature provides a formal theoretical construct which illustrates the relationship between an increase in immigrant population and wages of natives (e.g., Borjas 1999; Greenwood and Hunt 1995; Johnson 1998; Ottavano and Peri 2005; Chiswick et al. 1992). The basic tenet of the typical model is that assuming constant capital and constant returns to scale production technology, and perfect substitution between immigrants and natives, an increase in the supply of immigrants is expected to depress wages for natives.

This basic relationship can be sketched out in a simple model of labor market with immigration. We assume that there is a labor market in a closed economy over a two- 
period, $t(0$ and 1$)$, with $K$ occupations, indexed by $k$. Native workers $i$ are employed in occupation $k$ at time $t$, denoted by $N_{k i t}$. Suppose for simplicity that immigration occurs between the two periods, then employment of immigrants in occupation $k$ is denoted by $I_{k t}$. Total employment in any given occupation $E_{k t}$ is equal to $N_{k i \mathrm{t}}+I_{k t}$.

The ratio of immigrants to native workers $i$ is given by

$$
r_{k i t}=I_{k t} / N_{k i t}
$$

Assume that the labor market has a constant elasticity of demand function as follows:

$$
\operatorname{Ln}\left(E_{k t}\right)=\ln \left(D_{k}\right)+\eta \ln \left(W_{k i t}\right)
$$

where $D_{k}$ is a demand curve parameter that shifts the demand function (e.g., some occupations have higher demand for employment than others, for example, a dancer vs. a nurse). Assume that the labor market is in equilibrium in period 0, such that wages of workers $i$ are equalized across all occupations, with $W_{k \mathrm{i} 0}=W_{0}$ for all $k$. By definition in period 0 , total employment $E_{k 0}$ is equal to $N_{k 0}$.

The labor market equilibrium in period 0 is thus given by

$$
\operatorname{Ln}\left(N_{k i 0}\right)=\ln \left(D_{k}\right)+\eta \ln \left(W_{k i 0}\right)
$$

In period 1, which includes immigration, labor market equilibrium is given by

$$
\operatorname{Ln}\left(N_{k i 0}+I_{k i 1}\right)=\ln \left(D_{k}\right)+\eta \ln \left(W_{k i 1}\right)
$$

In a short-run framework, we assume labor market re-equilibration occurs slowly because workers do not change occupations easily in response to a change in relative wages, since it is costly to obtain additional occupation-specific human capital (Friedberg 2001). Then total native employment in occupations $k$ remains the same over the two periods $\left(N_{k 0}=N_{k 1}=N_{k}\right)$. Then, substituting the labor market equilibrium equation in period 0 into the labor market equilibrium equation in period 1 and rearranging the terms yields the following relationship between wages of natives and the proportion of immigrant workers:

$$
\operatorname{Ln}\left(W_{k i 1}\right) \approx \text { constant }+(1 / \eta) r_{k i 1}
$$

This simple labor market model yields the result that the presence of immigrants in occupation $k$ is inversely associated with wages of native workers $i$ in occupation $k$, after migration, assuming constant elasticity and perfect substitution of immigrants and natives (e.g., US-born) individuals.

\subsection{Substitution and complementarity of immigrants and natives}

In practice, the degree to which natives and immigrants are substitutes for one another varies depending on the type of occupations. Substitution between immigrants and natives may be higher in low-skilled occupations than in high-skilled occupations. This could be due to the fact that low-skilled occupations are more likely to have lower training costs, and require less institutional knowledge, while, high-skilled professional occupations (e.g., in the health and legal fields) might require licensing and other entry barriers, which lowers the degree of transferability of the skills of immigrants acquired in their country of origin (Friedberg 2001; Duleep and Regets 2002; Gallo and Bailey 1996). This suggests 
that there will be greater occupational clustering or segregation of immigrants in lowskilled occupations.

If immigrants and native workers are not substitutes for each other, but rather are complements in production, then an increase in immigrants' inflow into the labor market could raise the wages of native workers, especially as the latter reallocate into areas or sectors with higher wages, such as the natives taking on jobs that are more managerial or administrative (with certain language communication skills), which pay more (e.g., Greenwood and Hunt 1995; Johnson 1998; Ottavano and Peri 2005; Chiswick et al. 1992). The (negative) effect of immigrants on natives' wages may also be mitigated if natives are mobile because either they move out of places where immigrants are concentrated (Frey 1995) or they adjust their human capital and change occupations in the long term. Indeed, there is no consensus as to whether natives are mobile and respond to an influx of immigrants by moving to other areas (Card 2001; Kritz and Gurak 2001).

It has been shown that immigrants tend to adjust their human capital. The longer immigrants live in the USA, depending on the incentives they have and their efficiency in investing in US-specific human capital, the more institutional knowledge and language capital they acquire (Chiswick and Miller 1995). As a result, immigrants become more competitive with natives for jobs over time. Findings that immigrants experience a wage penalty when they first come in the USA and, subsequently, experience faster growth in their earnings are consistent with this "assimilation" perspective (Duleep and Regets 2002). All these suggest that ultimately the effect of immigration on natives' wages is a long-run phenomenon. ${ }^{1}$

\subsection{Previous empirical results}

The results of previous empirical studies on the impact of immigration have been mixed, and it has tended to depend on the methodological approach taken. A few studies have used natural experiments to isolate the effect of an influx of immigration on natives (i.e., Mariel boatlifts). This approach has yielded no significant impact of immigration on wages of natives (e.g., Card 1990; Hunt 1992; Carrington and de Lima 1996). Data based on random experiments are difficult to come by, limiting the use of this approach.

Several studies have exploited variations across geographies to estimate changes in the labor market outcomes of natives. They have found either no sizable effect of immigration on natives or a very small positive effect on natives, suggesting that there may be limited substitution between immigrants and natives in immigrant-receiving metropolitan areas (Altonji and Card 1991; Butcher and Card 1991; LaLonde and Topel 1991; Shoeni 1997; Card 2005). This approach is criticized because of the possibility of labor mobility-the effect of immigrants on natives could be mitigated if labor is mobile and move to other areas in response to an influx of immigrants (Card 2001; Kritz and Gurak 2001; Frey 1995). ${ }^{2}$

A few studies have taken a factor proportion approach to estimate the changes in the supply of different skill groups. For example, Borjas et al. (1992) used "skills" as an identification strategy defined by age/education/experience cell groups, to assess the impact of immigrants on natives with similar skills. This approach has yielded 
significantly larger (negative) effect of immigrants on natives. For example, Borjas and Katz (2005) find that Mexican immigration lowers wages of native high school dropouts by 4 to $8 \%$. Orrenius and Zavodny (2006) also used occupational variations in their study, and they find a negative impact on wages and employment of natives in low-skilled and low-waged occupations. The approach of this paper will be similar in spirit with the factor proportion approach.

We will also draw from the studies that have brought attention to the phenomenon of "task specialization". With task specialization, some immigrants and natives may not be competing for similar jobs. Peri and Sparber (2008) provide a formal model in which low-skill natives reallocate their labor by specializing into jobs that are intensive in "interactive production tasks" as opposed to "manual tasks" in which immigrants specialize in. They show that "task specialization" by immigrants causes natives with similar education to reallocate their own task supply into jobs requiring more interactive and communication skills. They show that as a result of increased specialization of immigrants, downward pressure on wages for less-educated natives has been reduced in states with large immigration flows. This paper asks a similar question regarding the impact of Mexican immigrants on wages of African-Americans. Of immediate interest will also be whether task specialization mitigates such impact.

\section{Empirical methodology}

\subsection{OLS baseline model}

The basic hypothesis that we are testing is whether the presence of Mexican immigrants in the given occupations lowers wages for African-Americans and the extent to which task specialization may mitigate this effect. We use a factor proportion approach using variations in occupations and considering various education/occupation/industry groupings, following some previous studies (e.g., Borjas and Katz 2005; Friedberg 2001). Recognizing that Mexican immigrants and African-Americans disproportionately work in distinct occupations, we use this fact to motivate the empirical strategy for identification, exploiting variations in the inflows into occupations across time to test the effect of Mexicans on wages of African-Americans. The key assumption is, given occupation-specific human capital, it might be harder to change occupations (compared to changing location). This would reduce the speed at which workers respond to changes in wages in occupations at least in the short run, creating a more persistent disequilibrium across occupations, from which to gage a potential effect of immigrants (Friedberg 2001).

To make clear the hypothesis we are testing, we first consider an OLS model, which tests the effect of the relative labor supply of Mexican immigrants in an occupation on the wages of African-American workers in that occupation. We consider a native's individual-level earnings function. The individual earnings function, as opposed to average wages approach, allows to control for factors that impact wages, such as secular changes in the returns to workers' education and labor market experience, as well as other lifecycle characteristics including age and marital status, in addition to immigration factors. Thus, using individual-level data has the advantage of added efficiency, relative to an analysis of mean occupational data, which might be more inclined to suffer omitted variable bias. The African-American individual-level reduced-form earnings function is specified as follows: 
$\operatorname{Ln} W_{i k t}=\alpha+\beta_{i} \mathrm{X}_{i t}+\gamma_{i k} r_{i k t}+\varepsilon_{i k t}$

where $\operatorname{Ln} w_{i k t}$ is the log of hourly earnings of the US-born individual $i$ in occupation $k$ at time $t ; \alpha$ is the constant term; $\beta_{i}$ is the coefficient of the vector of native individuals' demographic and lifecycle characteristics; $\mathrm{X}_{i t}$ is a vector of control demographic and lifecycle characteristics variables (which include schooling-level indicators, labor market experience, marital status, and age); and $\varepsilon_{i k t}$ is an individual-occupation-specific disturbance term, capturing the effect of unobservable variables that vary across individuals in each occupation, assumed to be normally distributed with mean zero and a homoscedastic variance. The main policy variable of interest is $r_{i k t}$. It indicates the relative presence of Mexican immigrants in the African-American's occupation. We measure this variable as follows:

$$
\text { where } r_{i k t}=\left(\frac{\frac{\text { total } \# \text { of immigrant worker group in occupation } k \text { at time } t}{\text { total number of immigrant worker group at time } t}}{\frac{\text { (total } \# \text { of all native workers } i \text { in occupation } k \text { at time } t)}{\text { total number of all native workers at time } t}}\right)
$$

By defining the concentration variable for each occupation as the ratio of the percent of immigrant (Mexican) in an occupation/industry over the percent of native (US-born African-Americans) in an occupation, we are retaining certain properties following how we expect the impact to operate. As constructed, this adjusted measure (as opposed to an unadjusted measure that is not a relative ratio) assumes that the impact is going to be driven in part by the relative size of the immigrant flows into the US-born individuals' occupations. A mean value for this measure that is equal to 1 (or equal to or close to 0 , in $\log$ form) means that the two groups (Mexican immigrants and AfricanAmerican workers) are equally represented in an occupation. In such instance, we would not expect a strong effect driven by the relative size of Mexicans in that occupation on the wage determination process for African-Americans. A value of more than 1 (or a positive value, in log form) means that there is a relative overrepresentation of Mexicans in the occupation, compared to African-Americans. The potential for a substitution effect or crowding out effect would be greater in such instance, and we might therefore expect to see greater wage pressures in those occupations' range for African-Americans, as a result of Mexicans in that occupation. A value of less than one (or a negative value, in log form) means that Mexicans are underrepresented or there is a relative shortage of Mexicans in that occupation. In such case, we do not expect a negative effect on wages for African-Americans in the occupation, stemming from Mexican immigrants.

Figure 1a-d shows the density distribution of this measure, by education category. The results show that Mexican immigrants have higher density in occupations with African-American workers with less than a high school education or who are high school dropouts. Mexican immigrants are close to twice as likely to be in those occupations, in which we find those African-Americans (most of the density distribution lie in the range $>0$ for the log of the adjusted ratio measure, in Fig. 1a, b). Mexican immigrants are somewhat equally likely to be in occupations in which we find African-Americans with a high school diploma (Fig. 1c). By contrast, Mexican immigrants are less likely to be in occupation in which we find college-educated African-Americans (most of the density distribution lie in the range <0, Fig. 1d). 


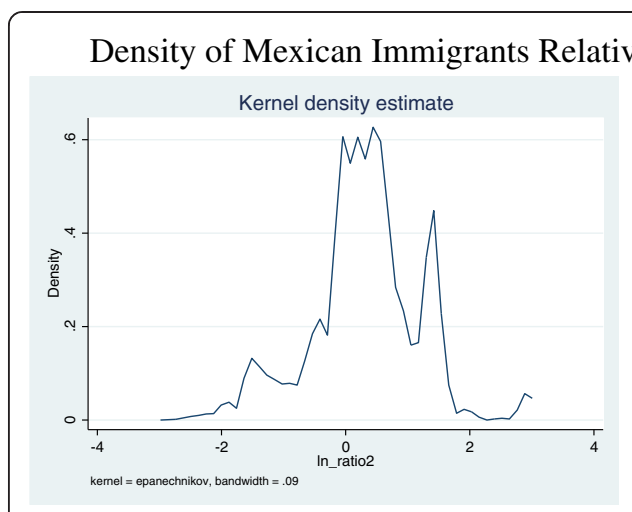

a Less than high school education

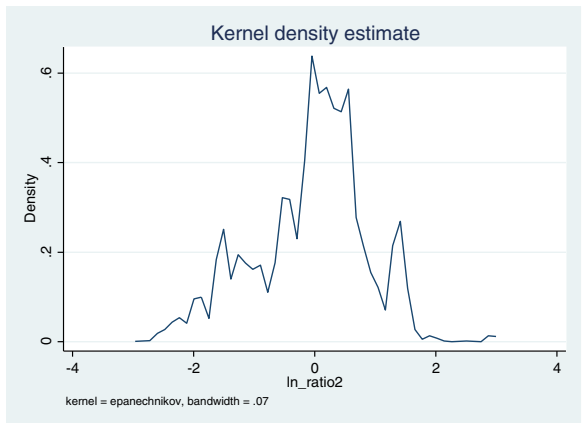

c High school graduates

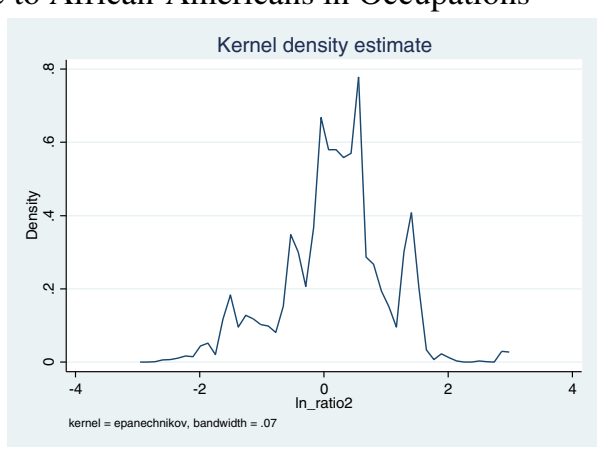

b High school dropout

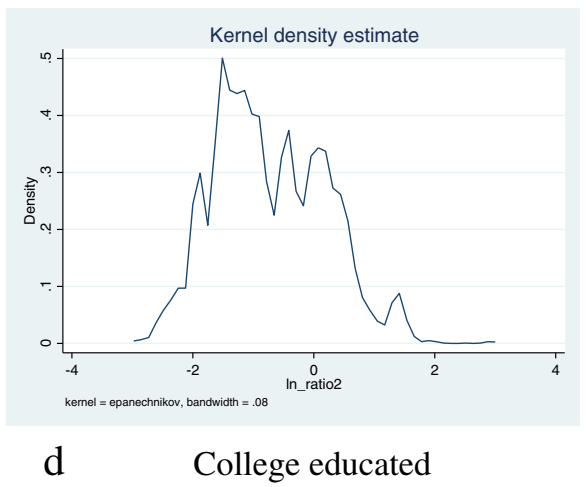

Fig. 1 Density of Mexican immigrants relative to African-Americans in occupations

\subsection{An instrumental variable model}

In the OLS framework described above, the assumption is that the distribution of immigrants and native workers across occupations, $r_{i k t}$, is exogenous to wages. In practice, this may not be the case. The variable $r_{i k t}$ indicating the occupation concentration ratio of immigrants relative to the natives' could be correlated with the error term $\varepsilon_{i k t}$ in the wage model (Eq. 2). This could happen, for example, if Mexican immigrants or African-Americans with lower unmeasured skills sort into occupations with lower skills, the exogeneity assumption would be violated, and the estimate $\gamma_{i k}$ would be bias. We therefore relax this assumption and conduct an instrument estimation procedure.

The instrumental variable method involves setting up a regression of occupation determination which breaks $r_{i k t}$ into two components-the part of $r_{i k t}$ that is correlated with the error term and the part that is uncorrelated with the error. In this setup, $r_{i k t}$ is on the left-hand size of the equation (the predicted variable), and some instrumental variables are the predictors. If those predictors are not correlated with the error term, then the component of $r_{i k t}$ that is related to the predictors will also be uncorrelated with the error term. This is expressed as follows:

$$
r_{i k t}=\pi_{0}+\pi_{1} \text { instrument } 1+\pi_{2} \text { instrument } 2+\ldots+v_{i t}
$$

The next step uses the predicted values $r_{i k t}$, from Eq. 3 with the error component now removed, as an instrument to get unbiased estimates of $\gamma_{i k}$ in the wage regression, as follows: 
$\operatorname{Ln} W_{i k t}=\alpha+\beta_{i} X_{i t}+\gamma_{i k} r_{i k t}^{\prime}+\varepsilon_{i t}$

\subsubsection{Instrumenting occupation composition of immigrants}

A source of independent variations in occupations can be found in past information on the occupation choice of Mexicans, following cross-discipline studies that have suggested that immigrants are likely to take jobs where previous cohorts have established (Zhou 1992; Waldinger and Der-Martirosian 2001; Mouw 2003; Kossoudji 1998; Lewis 2003; Card and Lewis 2005). We propose using as the first instrument a variable which captures the (past) labor -supply shocks of Mexicans into different occupations. It is defined as follows ${ }^{3}$ :

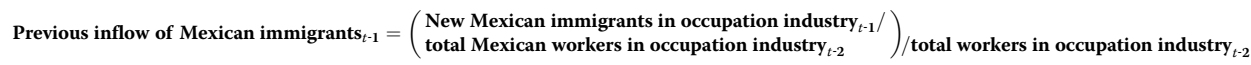

Waves of Mexican migration into the USA contain large numbers of individuals who are relatively less educated and who do not speak English. As such, Mexican immigrant workers are likely to have a comparative disadvantage in an occupation when the English language communication skills requirement is high. We therefore expect the Mexican immigrant labor supply shock into occupations in manual labor (e.g., landscaping) to be large, relative to occupations with higher English language/communication requirements (e.g., English teaching). By contrast, even if natives can do the manual work, they may not choose to do them to the same extent as Mexican immigrants. This follows the neoclassical theory which suggests that workers tend to choose occupations according to their relative comparative advantage in those occupations (Roy 1951). Also, empirical works (e.g., Autor et al. 2003; Peri and Sparber 2008) have shown that people tend to choose occupation according to the characteristics of the occupations and less-educated immigrants tend to choose certain types of manual occupations, which less-educated natives do not choose, even if they are able to perform the jobs.

We draw on information related to the task content of an occupation for a second instrument into the wage equation. Indeed arguably, the task involved in an occupation (manual relative to communication) may not fully be independent of wages and could therefore still be correlated with the error term in the wage equation. To illustrate, this can happen if there is differential returns to occupations given the task. Manual jobs, which Mexican immigrants may be clustered into, may be in such demand that the market is willing to reward them more. Communicative jobs such as receptionist or civil servant services, which African-Americans may have a comparative advantage in doing because they are fluent in English, may get rewarded less wage-wise (Catanzarite 2003).

To circumvent the potential endogeneity problem associated with the task content of an occupation, we use as instrument the residuals from a task-wage regression model $\left(\right.$ TASK $_{k t}=$ constant + hrlWage $_{k t}+$ error term $\left.{ }^{2 S R I}\right)$. The error terms' residuals, which we dub TASK_FITTED, are devoid of wage compensating differences associated with the task content of the occupations (since average hourly wage of that occupation is on the right-hand side in the task-wage regression). This is similar to the two-stage residual inclusion (2SRI) technique which was first proposed by Hausman (1978). This 
technique is also discussed in several econometrics papers and applied studies (e.g., Blundell and Smith 1989, 1993; Terza et al. 2009).

In our context, we are arguing that TASK_FITTED can be interpreted as capturing some otherwise unobservable variations in a Mexican occupation composition, stemming from labor supply shocks to an occupation related to ethnic/language/ transferable skill/network effects. The idea behind the 2SRI is pretty simple. If such task-related ethnic network effects which drive the immigrant workers to be clustered in certain occupations were known, then their value could be included among the observable controls in the occupation determination equation, and the endogeneity of occupation would cease to exist. Although we do not know the network effect coefficient, we can however obtain a consistent and good estimator of the true network value with the 2 SRI.

We restate the steps we take as follows:

$$
\begin{aligned}
& \text { TASK }_{k}=\text { constant }+ \text { log hrlwage } \\
& \text { Predict } 2 \text { 2SRI, TASK_FITTED } \\
& \text { Prror term } \\
& r_{i k t} t^{2}=\pi_{0}+\pi_{1} r_{i k t-1}+\pi_{2} \text { TASK_FITTED }+\ldots+v_{i t} \\
& \operatorname{Ln} W_{i k t}=\alpha+\beta_{i} X_{i t}+\gamma_{i k} r_{i k t}+\varepsilon_{i t}
\end{aligned}
$$

\section{Results}

\subsection{Data and descriptive statistics}

We make use of the 1980, 1990, and 2000 Public Use Micro Statistics (PUMS) $5 \%$ sample cross-sectional data from the US Census which allows us to exploit variations in Mexican immigrant cohorts' labor supply across time. Also, other advantages of using these data files are large sample size and occupation coverage. Using cross-sectional occupational data over time can present a challenge because of changes in occupation classifications. We circumvent this problem by using data with occupation crosswalks. ${ }^{4}$ Undercounting of Mexican immigrants due to the undocumented could also potentially be a drawback in these data and still remain somewhat of a limitation. ${ }^{5}$

The sample used for the empirical analysis consists of US-born individuals who identify themselves as being black (African-Americans) and people who identify themselves as having been born in Mexico, who are males, 18 to 64 years old, with positive earnings, who live in a metropolitan area, who are not self-employed, and who are not in the military.

Table 1 summarizes the average values of selected variables for Mexican immigrants and African-Americans in the data (Census 2000), not holding anything constant. The results suggest that Mexican immigrants tend to have lower wages than African-Americans on average and have also completed less schooling. In fact, over $50 \%$ of Mexicans do not have a high school degree. By contrast, only $20 \%$ of African-Americans do not have a high school diploma. Mexican immigrants work somewhat more hours on average, and they tend to be younger and more likely to be married. Just over $50 \%$ of Mexican immigrants report speaking only English at home or speak English well and very well. Over a quarter report not speaking English well, and the reminder report not speaking English at all. By 
Table 1 Summary statistics, socioeconomic characteristics

\begin{tabular}{lll}
\hline & African-American & Mexican immigrant \\
\hline Average years of labor market experience & 21.95 & - \\
Average years of schooling & 11.63 & 6.73 \\
Less than high school & 0.19 & 0.53 \\
High school & 0.35 & 0.17 \\
College graduate & 0.34 & 0.11 \\
Average age & 37.54 & 34.17 \\
Married & 0.45 & 0.63 \\
Do not speak English well or very well & - & 0.48 \\
Average number of weeks worked & 38.49 & 40.47 \\
Average number of hours worked a week & 36.02 & 38.68 \\
Average hourly wages (1999\$) & 16.83 & 13.17 \\
Average log of hourly wages (1999\$) & 2.50 & 2.27 \\
Wage ratio by 1-digit occupation grouping & & 0.82 \\
Farming & & 0.88 \\
Service & & 0.86 \\
Production & & 0.96 \\
Construction & & 1.05 \\
Sales/office & & 1.26 \\
Professional & & \\
\hline
\end{tabular}

Note: Labor market experience is defined as age-years of schooling -6, following Chiswick (1997). Source: Author's calculations based on the US Census $5 \% 2000$ PUMS data

contrast, close to $70 \%$ of US immigrant males report speaking English only, well, or very well (Toussaint-Comeau 2012).

Table 1 also reports the wage ratio by one-digit occupation groupings, measured as the ratio of Mexicans' average wages to the average wages of African-Americans. Mexican immigrants earn much less for each dollar earned by African-Americans in very low skill occupations (in terms of average educational requirement) such as farming and agriculture occupations, service, production, and construction. Mexican immigrants earn somewhat equally in semi-skill sales and office occupation grouping. However, on average, they earn more than African-Americans in broad higher skill professional occupation grouping.

In Table 2, we report the percentage of Mexican immigrants and AfricanAmerican workers in two-digit 23 occupation groupings. The occupation groupings are reported by decreasing order of average socioeconomic status. ${ }^{6}$ The corresponding average score of the manual/communication task intensity index (TASK) developed by Autor et al. (2003) is also reported in the table. ${ }^{7}$ This is a composite index that ranges from 0 to 10 , where the lower the number the lesser the value of manual relative to communication skills required in the occupations. These results suggest that Mexican immigrants are more concentrated in occupations that have relatively higher manual to communication task score and lower socioeconomic status (i.e., food preparation and serving; building and grounds cleaning; farming, fishing, and forestry; construction and extraction; production; and transportation and material moving occupations). African-Americans have relatively 
Table 2 Summary statistics: characteristics of occupations and percent of African-American and Mexican men in the occupations

\begin{tabular}{|c|c|c|c|c|}
\hline $\begin{array}{l}\text { 2-digit occupation } \\
\text { categories }\end{array}$ & $\begin{array}{l}\text { Socioeconomic } \\
\text { status score of } \\
\text { occupation }\end{array}$ & $\begin{array}{l}\text { Manual/language } \\
\text { TASK score of } \\
\text { occupation }\end{array}$ & $\begin{array}{l}\text { African-American } \\
\text { percent }\end{array}$ & $\begin{array}{l}\text { Mexican immigrant } \\
\text { percent }\end{array}$ \\
\hline Education, training, and library & 61 & 10.4 & 5.3 & 1.3 \\
\hline Management & 54 & 2.93 & 8.2 & 2.7 \\
\hline Business, fin. operations & 52 & 2.73 & 3.9 & 0.9 \\
\hline Computer and math. science & 51 & 3.2 & 2.2 & 0.3 \\
\hline Life, physical, social science & 49 & 4.3 & 0.9 & 0.2 \\
\hline Architecture and engineering & 49 & 4.2 & 1.9 & 0.4 \\
\hline Community and social services & 45 & 2.9 & 1.4 & 0.4 \\
\hline Arts, design, entertainment & 44 & 8.2 & 1.9 & 0.6 \\
\hline Legal & 42 & 5.1 & 1 & 0.1 \\
\hline Sales & 39 & 6.6 & 11.5 & 6.1 \\
\hline Protective services & 37 & 15.1 & 1.9 & 0.5 \\
\hline Healthcare & 36 & 7 & 4.2 & 0.6 \\
\hline Install., maintenance, repair & 33 & 7.9 & 3.9 & 3.8 \\
\hline Office and admin support & 30 & 5.8 & 15.5 & 6.9 \\
\hline Construction and extraction & 27 & 8.3 & 5.8 & 14.1 \\
\hline Production & 26 & 6.8 & 8.8 & 19.5 \\
\hline Healthcare support & 24 & 6.7 & 2.1 & 1.2 \\
\hline Transp. and material moving & 24 & 30.3 & 6.4 & 9.8 \\
\hline Personal care and service & 22 & 10.4 & 2.9 & 2.3 \\
\hline Building and grounds cleaning & 18 & 14.8 & 3.7 & 11.4 \\
\hline Food preparation and serving & 17 & 11.3 & 5.6 & 10.1 \\
\hline Farming, fishing, and forestry & 14 & 11.1 & 0.9 & 6.9 \\
\hline
\end{tabular}

Note: See text for further explanation. The socioeconomic status of an occupation is a composite index of human capital requirement to assess the quantitative meaning (in terms of relative wages and skill level) of each occupation derived from a wage regression model, following the methodology of Sicherman and Galor (1990). The ordinal scale ranges from 0 to 100 . The occupation task index is based on information from the Dictionary of Occupational Titles (DOT) that periodically evaluates the tasks required for more than 12,000 detailed occupations. The Census Occupation Codes were then organized into five categories: (1) manual skills-eye, hand, and foot coordination (EHF); (2) finger dexterity (FINGER); (3) direction, control, and planning (DCP); (4) general education math (MATH); and (5) sets limits and tolerance (STS). TASK in this table relates to the relative value of manual skills to communication skills for each occupation (the sum of EHF and FINGER over DCP). David Autor kindly provided this data and task computations to the author (Autor et al. 2003)

higher representation in occupations with lower manual to communication task score and higher socioeconomic status (i.e., professional occupations, protective services, and office administration).

It is of interest to know how occupations change with successive immigrant cohorts. As Borjas (1985) suggests, the "quality" of migration group changes over time, and if this is the case, there may be substantial differences in earnings potential across immigration cohorts, which would make accounting for "cohort effects" important. Tracing the top 20 occupations in which "new Mexican immigrants" enter in 1970-1980, 1980-1990, and 1990-2000, we find that over $60 \%$ of them in each cohort were in somewhat similar occupations. Appendix 1 lists those occupations.

In the immediate or longer term after migration, if there is rapid "assimilation" into the native's occupation, the impact of migration from a group might also change over time. Figure 2 shows the socioeconomic status score of occupations for Mexican immigrants (in the 2000 Census), by years since migration. (The figure also shows the same 


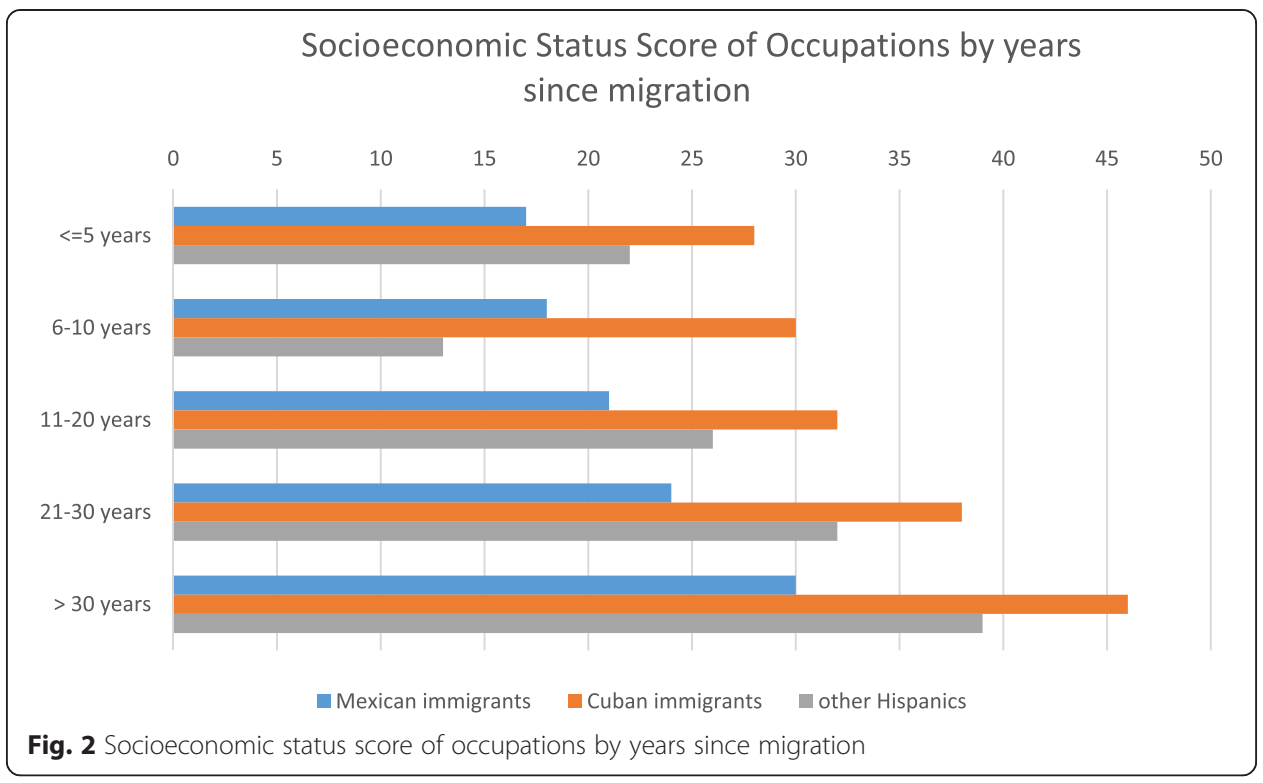

information for other Hispanic groups for comparison, since Mexicans make up over $60 \%$ of Hispanics.) The result suggests that consistent with "assimilation effects", the occupational socioeconomic status of immigrants tends to increase over time toward resembling that of the average US-born person. (On average, US-born workers have an occupational socioeconomic status score of 34.8. The US-born non-Hispanic Whites have an average score of 37.) Still, Mexican immigrants after years since migration are in occupations which, on average, score below that of the US-born person in terms of socioeconomic status. This result (while not shown in this table) is driven by the large portion of Mexicans who are not educated (Toussaint-Comeau 2006). The persistence in the similarity of the occupational profile of "new" Mexican immigrant cohorts over time, along with previous evidence that occupational assimilation into natives' occupations even after years of living in the USA is very low (for the less-educated Hispanic/ Mexican immigrants) suggest that the "cohort effect" and "assimilation effect" is smaller in the case of Mexican immigration, at least over the period covering this study.

\subsection{Empirical results}

We begin the empirical analysis by reporting in Table 3 the results from the first-stage individual-level OLS regressions of occupation concentration (Eq. 3) for the pooled sample and by education groupings. Column 2 to column 6, row 2 reports the coefficient estimate of the first instrument, previous inflow of Mexican immigrants. The estimated coefficients show that this relationship is positive and significant (e.g., for the pooled sample, coefficient $=0.0005$, standard error $=0.002$ ). This is consistent with the notion that the composition of Mexican immigrants across time tend to be homogenous and the past period's occupation of Mexican immigrants contributes significantly to explain the later period's occupation concentration of Mexican immigrants relative to African-Americans.

Column 2 to column 6, row 1 reports the coefficient estimate of the second instrument TASK_FITTED. The relationship is negative and significant for the pooled sample 
Table 3 First-stage determinant of occupation concentration

\begin{tabular}{|c|c|c|c|c|c|}
\hline & Pooled sample & Less than $\mathrm{HS}$ & HS dropouts & HS graduates & $\begin{array}{l}\text { College and } \\
\text { more }\end{array}$ \\
\hline Occupation TASK_FITTED & $\begin{array}{l}-0.008^{* * *} \\
(0.0011)\end{array}$ & $\begin{array}{l}-0.021^{* * *} \\
(0.0019)\end{array}$ & $\begin{array}{l}-0.0132^{* * * *} \\
(0.0012)\end{array}$ & $\begin{array}{l}-0.0082^{* * * *} \\
(0.0009)\end{array}$ & $\begin{array}{l}0.0030^{* * *} \\
(0.0009)\end{array}$ \\
\hline $\begin{array}{l}\text { Inflow of Mexican } \\
\text { immigrants } t_{t-1}\end{array}$ & $\begin{array}{l}0.0005^{* * *} \\
(0.0002)\end{array}$ & $\begin{array}{l}0.0009^{* * *} \\
(0.0002)\end{array}$ & $\begin{array}{l}0.0010^{* * * *} \\
(0.0002)\end{array}$ & $\begin{array}{l}0.0006^{* * *} \\
(0.0002)\end{array}$ & $\begin{array}{l}0.0002 \\
(0.0002)\end{array}$ \\
\hline Age & $\begin{array}{l}-0.138^{* * *} \\
(-0.006)\end{array}$ & $\begin{array}{l}-0.004 \\
(0.0140)\end{array}$ & $\begin{array}{l}-0.1075^{* * *} \\
(0.0141)\end{array}$ & $\begin{array}{l}0.0195^{* * *} \\
(0.0055)\end{array}$ & $\begin{array}{l}-0.1396^{* * *} \\
(0.0057)\end{array}$ \\
\hline Experience & $\begin{array}{l}0.1585^{* * *} \\
(0.0101)\end{array}$ & $\begin{array}{l}0.023 \\
(0.0229)\end{array}$ & $\begin{array}{l}0.1641^{* * *} \\
(0.0163)\end{array}$ & (Dropped) & $\begin{array}{l}0.1486^{* * *} \\
(0.0090)\end{array}$ \\
\hline Experience square/100 & $\begin{array}{l}-0.0479^{* * *} \\
(0.0206)\end{array}$ & $\begin{array}{l}-0.0183 \\
(0.0930)\end{array}$ & $\begin{array}{l}-0.1699^{* * *} \\
(0.0395)\end{array}$ & $\begin{array}{l}-0.0307 \\
(0.0239)\end{array}$ & $\begin{array}{l}-0.0436 \\
(0.0244)\end{array}$ \\
\hline Experience cube/1000 & $\begin{array}{l}0.0029 \\
(0.0027)\end{array}$ & $\begin{array}{l}0.0012 \\
(0.0098)\end{array}$ & $\begin{array}{l}0.0148^{* * *} \\
(0.0048)\end{array}$ & $\begin{array}{l}-0.0013 \\
(0.0032)\end{array}$ & $\begin{array}{l}0.0043 \\
(0.0035)\end{array}$ \\
\hline Married & $\begin{array}{l}-0.0815^{* * *} \\
(0.0236)\end{array}$ & $\begin{array}{l}-0.1054^{* * *} \\
(0.0441)\end{array}$ & $\begin{array}{l}-0.0381^{* * *} \\
(0.0547)\end{array}$ & $\begin{array}{l}-0.1046^{* * *} \\
(0.0308)\end{array}$ & $\begin{array}{l}0.0192 \\
(0.0368)\end{array}$ \\
\hline College & $\begin{array}{l}-0.1241^{* * *} \\
(0.0108)\end{array}$ & & & & \\
\hline College degree and more & $\begin{array}{l}-0.1683^{* * *} \\
(0.0200)\end{array}$ & & & & \\
\hline Constant & $\begin{array}{l}3.3588^{* * *} \\
(0.0773)\end{array}$ & $\begin{array}{l}1.757 \\
(0.2695)\end{array}$ & $\begin{array}{l}2.6989 \\
(0.2042)\end{array}$ & $1.035^{* * *}(0.114)$ & $\begin{array}{l}3.3672^{* * *} \\
(0.0924)\end{array}$ \\
\hline State fixed effects & Yes & Yes & Yes & Yes & Yes \\
\hline Number of observations & 223,688 & 9178 & 35,108 & 75,936 & 103,466 \\
\hline$R^{2}$ & 0.0838 & 0.0272 & 0.0218 & 0.0165 & 0.0364 \\
\hline \multicolumn{6}{|l|}{ F-statistics } \\
\hline Both instruments & 44.47 & 56.5 & 62.68 & 51.98 & 7.23 \\
\hline $\begin{array}{l}\text { Inflow of Mexican } \\
\text { immigrants }\end{array}$ & 10.61 & 9.62 & 12.33 & 12.3 & 1.35 \\
\hline $\begin{array}{l}\text { Occupation } \\
\text { TASK_FITTED }\end{array}$ & 47.86 & 111.92 & 81.95 & 81.95 & 12.48 \\
\hline
\end{tabular}

Note: The dependent variable is defined as the ratio of Mexicans to African-Americans in each occupation in year $2000=$ (Number of Mexican workers in an occupation-industry/Number of Mexican workers)/(Number of native African-American workers in an occupation-industry/Number of native African-American workers). TASK_FITTED is the residuals of a TASKwage regression. See text for more explanation

Robust standard errors in parentheses, clustered at the state level. ***Significantly different from zero at $99 \%$ confidence

(coefficient $=-0.01$, standard error $=0.001$ ), as well as for subsamples by education level (not college education/graduates). The negative coefficient suggests that otherwise task-related labor supply factors reinforces occupational divergence between Mexican and African-American workers.

Other factors related to the relative concentration of Mexicans in the AfricanAmerican individuals' occupation are held constant in this first-stage regression, and the results are consistent with expectation. As per their negative coefficients, AfricanAmerican individuals who are married, older, and who have college education tend to be in occupations with a lower proportion of Mexican immigrants.

Table 3 also includes results of $F$-statistics which test for the relevance and validity of the two instruments chosen. In other words, this test assesses whether or not the coefficients on both instruments $\pi_{1}$ and $\pi_{2}$ in Eq. 5 are zero. An F-statistic that is greater than 10 indicates that the instrument is relevant. Based on the results, our instruments are relevant. One exception is for the model which conditions on individuals having high skill (defined as having college education or college degree), as per the $F$-statistics 
$(=1.35)$, previous inflow of Mexican immigrants is not a really relevant instrument to predict later Mexican immigrant concentration relative to African-Americans.

Table 4 reports the main results measuring the impact of Mexican immigrants on wages of African-Americans (Eq. 5). It reports both the coefficient estimates of the Mexican presence variable on the log of hourly earnings, using OLS estimates without occupation fixed effects (column 2) as a baseline, OLS estimates with occupation fixed effects (column 3), and the IV estimates (columns 4 to 6). For the IV results, it reports coefficient estimates of the impact of Mexican immigrants from a first-stage occupation model which uses both instruments simultaneously (column 4), and then for two separate first-stage occupation models, each using one instrument, respectively (columns 5 and 6). (See Appendix 2 for the full regression OLS estimates.)

Table 4 Effects of Mexican immigrants on African-American male wages

\begin{tabular}{|c|c|c|c|c|c|}
\hline \multirow[t]{2}{*}{ Estimation procedure } & OLS & OLS & IV & IV & IV \\
\hline & $\begin{array}{l}\text { State fixed } \\
\text { effects }\end{array}$ & $\begin{array}{l}\text { State occupation } \\
\text { fixed effects }\end{array}$ & $\begin{array}{l}\text { Both } \\
\text { instruments }\end{array}$ & $\begin{array}{l}\text { Previous Mexican } \\
\text { immigrant inflow } \\
\text { instrument }\end{array}$ & $\begin{array}{l}\text { Occupation } \\
\text { TASK_FITTED } \\
\text { instrument }\end{array}$ \\
\hline \multicolumn{6}{|l|}{ Pooled sample } \\
\hline $\begin{array}{l}\text { Mexican occupation } \\
\text { concentration }\end{array}$ & $\begin{array}{l}-0.033^{* * *} \\
(0.002)\end{array}$ & $-0.012^{* * *}(0.005)$ & $\begin{array}{l}-0.191^{* * *} \\
(0.091)\end{array}$ & $\begin{array}{l}-0.076 \\
(0.086)\end{array}$ & $\begin{array}{l}-0.233^{* * *} \\
(0.101)\end{array}$ \\
\hline $\begin{array}{l}\text { Overidentification } \\
\text { J-test }\end{array}$ & & & 1.9878 & & \\
\hline$P$ value & & & 0.1586 & & \\
\hline \multicolumn{6}{|c|}{ Less than High School education } \\
\hline $\begin{array}{l}\text { Mexican occupation } \\
\text { concentration }\end{array}$ & $\begin{array}{l}-0.024^{* * *} \\
(0.004)\end{array}$ & $\begin{array}{l}-0.026 \\
(0.019)\end{array}$ & $\begin{array}{l}0.053 \\
(0.096)\end{array}$ & $\begin{array}{l}0.285 \\
(0.235)\end{array}$ & $\begin{array}{l}0.011 \\
(0.009)\end{array}$ \\
\hline $\begin{array}{l}\text { Overidentification } \\
J \text {-test }\end{array}$ & & & 1.6932 & & \\
\hline$P$ value & & & 0.1932 & & \\
\hline \multicolumn{6}{|l|}{ High School dropouts } \\
\hline $\begin{array}{l}\text { Mexican occupation } \\
\text { concentration }\end{array}$ & $\begin{array}{l}-0.016^{* * *} \\
(0.002)\end{array}$ & $\begin{array}{l}-0.008 \\
(0.009)\end{array}$ & $\begin{array}{l}-0.035 \\
(0.044)\end{array}$ & $0.049(0.067$ & $\begin{array}{l}-0.029 \\
(0.065)\end{array}$ \\
\hline $\begin{array}{l}\text { Overidentification } \\
\text { J-test }\end{array}$ & & & 0.0343 & & \\
\hline$P$ value & & & 0.853 & & \\
\hline \multicolumn{6}{|l|}{ High School graduates } \\
\hline $\begin{array}{l}\text { Mexican occupation } \\
\text { concentration }\end{array}$ & $\begin{array}{l}-0.030^{* * *} \\
(0.002)\end{array}$ & $\begin{array}{l}-0.009 \\
(0.007)\end{array}$ & $\begin{array}{l}-0.202^{* * *} \\
(0.013)\end{array}$ & $\begin{array}{l}0.075 \\
(0.091)\end{array}$ & $\begin{array}{l}-0.329^{* * *} \\
(0.127)\end{array}$ \\
\hline $\begin{array}{l}\text { Overidentification } \\
\text { J-test }\end{array}$ & & & 9.2307 & & \\
\hline$P$ value & & & 0.0024 & & \\
\hline \multicolumn{6}{|c|}{ College educated and more } \\
\hline $\begin{array}{l}\text { Mexican occupation } \\
\text { concentration }\end{array}$ & $\begin{array}{l}-0.071^{* * *} \\
(0.016)\end{array}$ & $\begin{array}{l}-0.014^{* *} \\
(0.008)\end{array}$ & $\begin{array}{l}1.543^{* * *} \\
(0.670)\end{array}$ & $\begin{array}{l}-0.720 \\
(0.874)\end{array}$ & $\begin{array}{l}1.049^{* * *} \\
(0.305)\end{array}$ \\
\hline $\begin{array}{l}\text { Overidentification } \\
\text { J-test }\end{array}$ & & & 2.4077 & & \\
\hline$P$ value & & & 0.1207 & & \\
\hline
\end{tabular}

Note: Each coefficient is from a separate regression that controls for age, experience, experience squared, experience cubed, married, and state fixed effects, (college, post-graduate, in the pooled regressions). Dependent variable is the log of hourly wages of African-Americans. Robust standard errors in parentheses

***significantly different from zero at 99 percent confidence. ${ }^{* *}$ significantly different from zero at 95 percent confidence 
We also report in Table 4, the results of $J$-test of overidentifying restrictions that verify whether or not both instruments are exogenous. In essence, this tests for the following hypotheses:

$H_{0}: R_{i k t-1}$ and TASK_FITTED are exogenous (not correlated with the error term). $H_{a}: R_{i k t-1}$ and TASK_FITTED or both are not exogenous (correlated with the error term).

For this test, the $P$ value should be more than 0.05 in order to reject the null hypothesis that the instruments are correlated with the error terms. ${ }^{8}$ As can be seen as per the $P$ values reported in Table 4, we can reject the null hypothesis that one or both of these instruments are endogenous for the pooled sample and for the subsamples. The one exception is the subsample of the African-Americans who are high school graduates, and the result for this group is subject to some concerns that one or both of the instruments may be endogenous (the $P$ value is less than 0.05 ). With these caveat in mind, we turn to discussing the estimates.

Looking closely in Table 4, the coefficient estimates of Mexican immigrants' presence in an occupation in the OLS baseline model are negative and significant. The coefficient estimates are less negative in the OLS with occupation fixed effects, but not entirely erased. The fact that we still find a significant relationship between the ratio of Mexican immigrant concentration and wages of African-American, after we control for occupation fixed effects, suggests that the negative relationship between Mexican immigrants and African-American wages is isolated and not entirely coming from the effects of occupational differences.

The IV estimate for the pooled sample is more negative than the OLS model estimates with and without occupation fixed effects. The difference between the OLS estimate of Mexican immigrant effect (-0.033), the occupation fixed-effects model estimate $(-0.015)$, and the IV model estimate $(-0.191)$ for the pooled sample suggests that the distribution of Mexican immigrants and African-American workers across occupations is not completely independent of the unobserved determinants of wages in those occupations, justifying our additional instrument variable modeling approach. Overall, the results for the pooled sample are suggestive of potential crowding out effects for African-Americans in the labor market, as a result of Mexican immigration.

Looking more closely at the IV coefficient estimates and the occupation fixed-effect estimates by education level, we note that the results are not statistically significant for African-Americans who have no high school education and those who are high school dropouts, respectively. In other words, Mexican immigrants, unlike in the OLS model which does not control for occupation selection, do not affect African-Americans with low skills. This is consistent with Card and Lewis (2005) who found that Mexican immigrants have no impact on low-skilled workers who are high school dropouts, as well as Peri and Sparber (2008) who argue that due to task specialization, low-skill natives and immigrants are not competing for the same jobs.

By contrast, Mexicans' presence in an occupation according to the IV estimate coincides with depressing wages for African-Americans who are high school graduates (in intermediate-skill-range occupations) and corresponds with increased wages for African-Americans with college education (in high-skill-range occupations). 


\subsection{Interpreting the effect of Mexican immigrants on wages of African-Americans}

The size of the immigrant flows must be large enough to have any measurable impact. To have a better idea of the economic significance of the coefficient estimates, we consider the relative size of the Mexican labor supply in the given occupations, by weighting the coefficient estimates (from Table 4) by the mean value of the measure of the ratio of Mexican immigrants in the occupations. The results are reported in Table 5.

Recall that the Mexican concentration variable is defined as the ratio of the percent of Mexicans in an occupation over the percent of African-Americans in an occupation. The mean value of the ratio of Mexican to African-American concentration in an occupation for the pooled sample is 1.19, which means that overall, Mexican immigrants are as represented as African-Americans over the range of occupation spectrum. For the IV coefficient estimate of -0.19 for the pooled sample, the implied effect of the somewhat equal concentration of Mexican immigrants in an occupation corresponds with a $2.3 \%$ decrease in wages for African-American workers $(-0.19 \times 1.19=-0.226)$.

Now, consider the effect on African-Americans who are high school graduates, for whom we find a statistically significant coefficient of -0.202 for the Mexican concentration variable. The mean value of the ratio of Mexicans to African-Americans in those occupations is 1.34, which suggests that Mexicans are highly represented in those occupations in which we find also African-Americans who are high school graduates (see Fig. 1c). Therefore, for the IV coefficient estimate value of -0.202 , the implied effect of the overrepresentation of Mexican immigrants in these occupations is a $2.7 \%$ decrease in wages for African-Americans $(-0.202 \times 1.34=-0.271)$.

The ratio of Mexicans to African-Americans in occupations where the African-Americans have a college education is 0.75 , which suggests that Mexican immigrant concentration in those occupation ranges is low (see Fig. 1d). For the IV estimate for which we find a coefficient of 1.543, the lack of the presence of Mexicans in those occupations corresponds to $12 \%$ higher wages for African-Americans with a college degree $(0.75 \times 1.543=11.6)$.

\section{Accounting for occupation segmentation in local labor markets}

One of the more puzzling results we have found is that in spite of the fact that Mexican immigrants are heavily concentrated in occupation groupings in which we find African-Americans with less education (high school dropouts), there is no statistically significant effect on this group from Mexican immigrants. To better understand the labor market wage adjustments of African-Americans in the context of strong occupational segregation, we consider an alternative specification of the

Table 5 Relative size of Mexican labor supply in the African-American individual's occupation and its impact on wages of African-Americans

\begin{tabular}{|c|c|c|c|c|c|c|}
\hline & & Pooled sample & $\begin{array}{l}\text { Less than } \\
\text { high school }\end{array}$ & $\begin{array}{l}\text { High school } \\
\text { dropouts }\end{array}$ & High school & College \\
\hline \multirow{3}{*}{$\begin{array}{l}\text { Mexican occupation } \\
\text { concentration }\end{array}$} & Mean & 1.19 & 1.97 & 1.66 & 1.34 & 0.75 \\
\hline & $\begin{array}{l}\text { IV-both } \\
\text { instruments }\end{array}$ & $-0.226^{* * *}$ & 0.104 & $-0.058^{* * *}$ & $-0.271^{* * *}$ & $1.160^{* * *}$ \\
\hline & OLS & $-0.392^{* * *}$ & $-0.472^{* * *}$ & $-0.027^{* * *}$ & $-0.040^{* * *}$ & $-0.053^{* * *}$ \\
\hline
\end{tabular}

Note: Each value is from a separate regression coefficient estimate of the effect of Mexican occupation concentration multiplied by the corresponding reported mean value of that concentration measure. ${ }^{* * *}$ the effect is significantly different from zero at 99 percent confidence 
relationship between occupation concentration and wages of African-Americans. To be clear how we are proceeding with this complementary exercise, we can state the relationships we are testing as follows ${ }^{9}$ :

$$
\begin{aligned}
& \operatorname{Ln} W_{i h k}=\sum \beta_{k h} \mathrm{X}_{i k h}+\theta_{h} H I S P_{i h}+\left(\phi_{k h+} \Phi_{i h}\right) \\
& \operatorname{Ln} W_{i n k}=\sum \beta_{k n} \mathrm{X}_{i k n}+\theta_{n} H I S P_{i n}+\left(\phi_{k n+} \Phi_{i n}\right)
\end{aligned}
$$

where $h$ and $n$ are subscripts indicating the foreign-born Hispanic/Mexican and native (US-born Blacks/African-Americans) individuals, respectively; $\ln W_{i}$ is the $\log$ of yearly wages of individual $i$ in occupation $k$; $\beta_{k h}$ are the coefficients of the variables in the vector $\mathrm{X}_{i k}$; and $\theta_{h}$ is the coefficient of the Hispanic/Mexican immigrant concentration. The last two terms of the above relationship relates to the error structure of the model. Unobserved occupational-specific effects on wages are assumed to be captured in $\phi_{k}$, while $\Phi_{i}$ is an individual-specific disturbance term, relating to the effects of unobservable variables that vary across individuals. $\phi_{k}$ is assumed to be normally distributed with mean zero and a homoscedastic variance. $\Phi_{i}$ is assumed to be a sequence over $i$ that consists of normal $i$, i.d. random variables with mean zero and a constant variance.

$\mathrm{X}_{i k}$, indexed by $k$ occupations, is the intercept and a vector of observable socioeconomic and demographic individual and characteristics, including indicator variables such as marital status, age, and educational attainment. This vector also includes location fixed effects (which control for differences in location characteristics of the labor market.

$H I S P_{i}$ is the Hispanic/Mexican immigrant density in the worker i's occupation-in a way, the variable HISP can be interpreted as the degree of the "Hispanicness" or "Mexicaness" of an occupation. The variable HISP represents a key feature of the model, in that it assumes that the high degree of Hispanic occupational segregation distinguishes the Hispanic immigrant from the native's employment structure. (We can therefore estimate separate earnings functions (5) and (6) for Hispanic/Mexican immigrants $(h)$ and natives $(n)$, since we are allowing the effects of the Hispanic composition of the occupation to differ by the two groups.)

The core interest in this model for the purpose of examining the linkage between Hispanic occupation composition and earnings is the relation between wages and HISP, captured via the coefficients $\theta_{h}$ and $\theta_{n}$. The signs of these coefficients are theoretically ambiguous. The interpretation of the HISP coefficients depends on the underlying causes for the occupational segregation of the two groups and on the ways HISP and wages are related.

If $\theta_{h}<0$, this suggests that wages of Hispanic/Mexican immigrants compresses as the Hispanic/Mexican proportion in the occupation rises, perhaps this is due to occupational crowding, assuming that inter-occupational mobility is not enough to equalize wages.

$\theta_{h}>0$ would be consistent with the perspective, whereby people choose work, which provides them with the highest returns given their skills. For example, a sector that becomes dominated by an ethnic group reflects the fact that the particular group may have a comparative advantage in being in that sector. As noted previously, such proposition is also consistent with the hypothesis of "ethnic hegemony" which suggests that the increase in the relative size of a given population in a workplace/occupation 
enhances the negotiating power of the group, leading to higher returns (Jibou 1988; Aldrich et al. 1985; Portes and Bach 1985; Zhou 1992).

If $\theta_{n}<0$, this suggests that natives obtain a sort of "wage penalty" for being in predominantly Hispanic/Mexican occupations. We note that if natives do not face similar barriers like Hispanics/Mexicans may face (e.g., language barriers, lack of knowledge of institutions, and lower transferability of skills and education acquired abroad), there is no reason to believe that they should deliberately accept lower wages that predominate in the Hispanic/Mexican occupations, when other occupations with relatively lower wage pressures may be available. Hence, if $\theta_{n}<0$, one could expect that natives would be less attracted by predominantly Hispanic/Mexican occupations. If Hispanics/ Mexicans face barriers to better-paying occupations, low-wage occupations would attract a disproportionately large number of them and a small proportion of natives, resulting in a negative relation between HISP and wages of Hispanics and natives.

$\theta_{n}<0$ signals in a way that the Hispanicness or Mexicaness of an occupation may serve as a "quality sorting" mechanism for natives. In the sense that if Hispanic/Mexican immigrants are concentrated in low-pay occupations due to certain barriers, and natives are not, over time, these occupations attract more low-skill natives (as they attract lessand-less-skilled natives). As a result, all workers, natives, and Hispanics in predominantly Hispanic occupations would have lower average wages.

If $\theta_{n}>0$, this would indicate that natives are rewarded differently in predominantly Hispanic/Mexican immigrant occupations. Such result would be consistent with the prediction of a model of employers' tastes for discrimination. If such is really the case, over time, natives would be attracted to the Hispanic occupations, leading to lower average wages.

The results of estimating Eq. 7 are reported in Table 6. Focusing on the impact on African-Americans, the OLS result (in column 1) shows that higher Mexican immigrant shares in the metropolitan area are associated with small positive wage effects, $0.6 \%$ increase in the wages of African-Americans. It is unclear what relevant local labor market (geographic level of the analysis) needs to be taken into account to capture the relationship between wages of African-Americans and the share of the Mexican immigrant population. We consider an alternative geographic dimension of the local labor market other than the metropolitan area. The share of Mexican immigrants is redefined at a smaller geographical unit, the PUMA (Public Use Micro Statistic Area). Defined at the PUMA level, the positive effect of the share of Mexican immigrants is reversed. In column 2, a $1 \%$ increase in the share of Mexican immigrants in the PUMA corresponds to $8.4 \%$ decreases in wages for African-Americans. Therefore, it appears that the effect of the Hispanic population depends on the definition of the local labor market.

In column 3, we include MSA (Metropolitan Statistical Area) fixed effects in the model. Once we control for MSA fixed effects in the OLS specification, higher shares of Mexican immigrant in the PUMA are associated with much lower negative wage effects on African-Americans. Here, a 1 percentage point increase in the share of Mexican immigrants in the PUMA corresponds to a decrease in African-American workers' wages of $3 \%$, as opposed to an $8.4 \%$ decrease, without the control for MSA fixed effects. Thus, not accounting for location selection substantially overestimates the (negative) effects of Hispanics on natives. 
Table 6 Estimates of the relationship between black natives' wages, Mexican shares in the local labor market, and ethnic/racial occupation density

\begin{tabular}{|c|c|c|c|c|c|}
\hline \multirow[t]{2}{*}{ Panel 1} & \multirow[t]{2}{*}{ (1) } & \multirow[t]{2}{*}{ (2) } & \multirow[t]{2}{*}{ (3) } & \multirow{2}{*}{$\begin{array}{l}\text { (4) } \\
\text { Integrated }\end{array}$} & \multirow{2}{*}{$\begin{array}{l}\text { (5) } \\
\text { Hispanic } \\
\text { dominated }\end{array}$} \\
\hline & & & & & \\
\hline OLS & $\begin{array}{l}\text { All } \\
\text { occupation }\end{array}$ & $\begin{array}{l}\text { All } \\
\text { occupation }\end{array}$ & $\begin{array}{l}\text { All } \\
\text { occupation }\end{array}$ & Occupation & Occupation \\
\hline Mexican shares in the MSA & $\begin{array}{l}0.005^{* * *} \\
(0.0006)\end{array}$ & - & - & - & - \\
\hline Mexican shares in the PUMA & - & $\begin{array}{l}-0.084^{* * *} \\
(0.005)\end{array}$ & $\begin{array}{l}-0.03^{* * *} \\
(0.007)\end{array}$ & $\begin{array}{l}-0.038^{* * *} \\
(0.009)\end{array}$ & $-0.021^{*}(0.012)$ \\
\hline $\begin{array}{l}\text { Hispanic immigrant occupation } \\
\text { density }\end{array}$ & $\begin{array}{l}-0.029^{* * *} \\
(0.002)\end{array}$ & $\begin{array}{l}-0.029^{* * *} \\
(0.002)\end{array}$ & $\begin{array}{l}-0.027^{* * *} \\
(0.002)\end{array}$ & $\begin{array}{l}-0.082^{* * *} \\
(0.008)\end{array}$ & $\begin{array}{l}-0.029^{* * *} \\
(0.011)\end{array}$ \\
\hline $\begin{array}{l}\text { U.S.-born African-American occu- } \\
\text { pation density }\end{array}$ & $\begin{array}{l}-0.095^{* * *} \\
(0.004)\end{array}$ & $\begin{array}{l}-0.095^{* * *} \\
(0.003)\end{array}$ & $\begin{array}{l}-0.094^{* * *} \\
(0.003)\end{array}$ & $\begin{array}{l}-0.124^{* * *} \\
(0.005)\end{array}$ & $\begin{array}{l}-0.081^{* * *} \\
(0.005)\end{array}$ \\
\hline $\begin{array}{l}\text { U.S.-born White occupation } \\
\text { density }\end{array}$ & $\begin{array}{l}0.186^{* * *} \\
(0.004)\end{array}$ & $\begin{array}{l}0.186^{* * *} \\
(0.003)\end{array}$ & $\begin{array}{l}0.184^{* * *} \\
(0.004)\end{array}$ & $\begin{array}{l}0.263^{* * *} \\
(0.005)\end{array}$ & $0.212^{* * * *}(0.011)$ \\
\hline MSA fixed effects & No & No & Yes & Yes & Yes \\
\hline \multicolumn{6}{|l|}{ Panel 2} \\
\hline \multicolumn{6}{|l|}{$2 S L S$} \\
\hline Mexican shares in the MSA & $\begin{array}{l}0.005^{* * *} \\
(0.0005)\end{array}$ & - & - & - & - \\
\hline Mexican shares in the PUMA & - & $\begin{array}{l}-0.087^{* * *} \\
(0.006)\end{array}$ & $\begin{array}{l}-0.033^{* * *} \\
(0.007)\end{array}$ & $\begin{array}{l}-0.022^{*} \\
(0.009)\end{array}$ & $0.02(-0.017)$ \\
\hline $\begin{array}{l}\text { Hispanic immigrant occupation } \\
\text { density }\end{array}$ & $\begin{array}{l}-0.015^{* * *} \\
(0.002)\end{array}$ & $\begin{array}{l}-0.014^{* * *} \\
(0.002)\end{array}$ & $\begin{array}{l}-0.013^{* * *} \\
(0.002)\end{array}$ & $\begin{array}{l}-0.083^{* * *} \\
(0.008)\end{array}$ & $\begin{array}{l}-0.029^{* * *} \\
(-0.003)\end{array}$ \\
\hline $\begin{array}{l}\text { U.S.-born African-American occu- } \\
\text { pation density }\end{array}$ & $\begin{array}{l}-0.089^{* * *} \\
(0.003)\end{array}$ & $\begin{array}{l}-0.089^{* * *} \\
(0.003)\end{array}$ & $\begin{array}{l}-0.088^{* * *} \\
(0.003)\end{array}$ & $\begin{array}{l}-0.124^{* * *} \\
(0.005)\end{array}$ & $\begin{array}{l}-0.08^{* * *} \\
(-0.002)\end{array}$ \\
\hline $\begin{array}{l}\text { U.S.-born White occupation } \\
\text { density }\end{array}$ & $\begin{array}{l}0.057^{* * *} \\
(0.157)\end{array}$ & $\begin{array}{l}0.0156^{* * *} \\
(0.004)\end{array}$ & $\begin{array}{l}0.155^{* * *} \\
(0.004)\end{array}$ & $\begin{array}{l}0.263^{* * *} \\
(0.005)\end{array}$ & $0.212^{* * *}(0.011)$ \\
\hline Lambda & $\begin{array}{l}-0.023^{* * *} \\
(0.002)\end{array}$ & $\begin{array}{l}-0.025^{* * *} \\
(0.002)\end{array}$ & $\begin{array}{l}-0.024^{* * *} \\
(0.001)\end{array}$ & $\begin{array}{l}0.117^{* * *} \\
(0.027)\end{array}$ & $0.184^{* * *}(0.05)$ \\
\hline MSA fixed effects & No & No & Yes & Yes & Yes \\
\hline Number of observations & 235,918 & 235,918 & 235,918 & 151,979 & 83,946 \\
\hline
\end{tabular}

Note: Dependent variable is the log of hourly wages of African-American males. Other variables control for, not reported are age, experience, maried, education. Robust standard errors are reported in parentheses. ${ }^{* *}$ significantly different from zero at 99 percent confidence. * significantly different from zero at 90 percent confidence

The occupation density of the different groups is also controlled for in all the specifications reported. In columns 2 and 3, the results are robust to control or no control of MSA fixed effects. The OLS result in each of these two specifications shows that increases in the density of Hispanic immigrants in an occupation correspond to a decrease in wages of African-Americans, hovering around $3 \%$. Based on our theoretical premise, an interpretation of this result is that there is a "penalty" in terms of wages for African-Americans to be in occupations that have strong representation by Hispanics.

We note however that the coefficient of the variable proxying the density of AfricanAmericans is more negative on wages of African-Americans than the coefficient of the Hispanic density. Here, a 1 percentage point increase in the density of AfricanAmericans in an occupation corresponds to a decrease in wages of $9.5 \%$. Following the theoretical logic mentioned previously, this suggests that there may be occupational 
crowding. By contrast, a higher occupation density of Whites in an occupation corresponds to positive wages for African-American workers. An interpretation for this result may be that the racial/ethnic density in occupations reflects differences in the degree of skills/education of individuals in the occupations that are not captured in the education, experience, and other personal characteristics controlled for in the model. As such, the results might simply indicate that the returns are higher in more skilled occupations (e.g., white-dominated occupations).

Next, in columns 4 and 5, we condition the regressions on occupation groups to test whether the impact on wages of the share of Mexican immigrants in the PUMA and of the occupation density of the three groups vary depending on the type of occupation. We proceed as follows: There are 475 in all in the 2000 PUMS. We classify them into two categories-whether there are Hispanicdominated occupations or are not Hispanic-dominated occupations. This is an ad hoc measure whereby, if the concentration ratio of the Hispanic population over the total workforce in each of those occupations is over 1.3, then the occupation is classified as Hispanic dominated; otherwise, if it is less, it is considered nonHispanic dominated.

For African-Americans in "Hispanic occupations", a 1 percentage point increase in the share of Mexican immigrants in the PUMA is associated with a decrease in wages of $2.1 \%$. By contrast, for African-Americans in integrated, non-Hispanic-dominated occupations, a 1 percentage point increase in the share of Mexican immigrants in the PUMA corresponds to a stronger decrease in wages of $3.8 \%$. Similarly, for AfricanAmericans in "Hispanic occupations", a 1 percentage point increase in the density of Hispanic immigrants in those occupations corresponds to a decrease in wages for African-Americans of $2.9 \%$. For African-Americans in more integrated occupations, a 1 percentage point increase in the density of Hispanic immigrants in those occupations is associated with an $8.2 \%$ decrease in wages. These results suggest that, contrary to what intuition might dictate, there is stronger pressure on wages of African-Americans in the more integrated occupations than there is in occupations with a strong Hispanic immigrant niche. In other words, African-Americans compete, to a lesser degree, in "Hispanic occupations" with strong market segmentation, while the more relevant "competition" between African-Americans and Hispanic immigrants may be in more integrated, possibly semi-skilled occupations, such as production and transportation, or even more-skilled professional occupations.

The bottom panel of Table 6 shows the result of a 2SLS estimate procedure. As mentioned before, due to various factors, Hispanics are heavily concentrated in low-skilled occupations. As such, occupation choice may be endogenously determined, which support a 2SLS technique. ${ }^{10}$ The 2 SLS estimation procedure produces results that are closely similar to the OLS. One exception in column 5 of panel B is where we control for occupation selection with this estimation procedure and condition the model on whether the occupations in question are Hispanic dominated. This result indicates that occupation segregation mitigates the effect of Mexican immigrants on AfricanAmericans in local labor markets. By contrast as per the 2SLS estimates, an increase in the percent of African-Americans in an occupation is still significant, ranging from a $12 \%$ decline if in integrated occupations and an $8 \%$ decline if in a Hispanic/Mexicandominated occupations. 


\section{Conclusions}

Since the 1970s, economic restructuring have shifted the structure of industries in the economy and have morphed the occupational path of workers, changing the prospect of socioeconomic upward mobility for many-since the 1980s, wages of AfricanAmerican workers have stagnated. As less-educated Hispanics/Mexican immigrants have been absorbed in various sectors, particularly the less-skilled sectors, a natural tendency has been to ask whether the trend in African-American wages and labor market experience and outcomes is tied to or attributed to Mexican immigration.

The finding in this paper suggests that the effect of Mexicans could be consequential and is being felt on a broader wage structure. We consider three different model alternatives to examine the effect of Mexican immigrants on wages for African-Americans, a baseline OLS model, an OLS with occupation fixed-effects model, and an instrumental variable model. The OLS and fixed-effects estimates, the IV estimates, or the occupation selection model estimates all point to an inverse relationship between Mexican immigrants and wages for African-Americans. That is, the higher the proportion of Mexican immigrants is in an occupation, the higher is the tendency for wages to depress for workers in those occupations. This finding is consistent with the prediction of a crowding out effect or substitution effect in the labor market immigration model.

Starting from underlying assumptions about differences in the occupational distribution profiles of Mexican immigrants and African-Americans, we ask whether divergence in occupation profile (specialization) would tend to mute the effect of Mexican immigrants on wages of African-Americans. We conduct an analysis which assesses the effect of immigration in the context of strong occupational segregation and polarization, and tests what it means for occupation to be heavily represented by a group, whether in relative adjusted terms or in absolute terms.

We find no statistically significant effect of Mexican immigrants on wages, for lowerskill range occupations. By contrast, Mexican immigrants' impact tends to be felt more on African-Americans with high school education, suggestive of a greater potential for crowding out effects or spillover effects in the intermediate-skill range. (Spillover effects signify that African-Americans move to occupations because of high wage pressures in lower skilled occupations with high concentration of Mexicans but, as a result, crowd out the more intermediate-skill occupations, resulting in wage pressure there.) At the high-skill range, occupations where workers are college graduates, the relationship between Mexican and wages is positive, which suggests that there is more complementarity in the production process between more-educated Mexican immigrants and African-American workers.

In addition, this paper shows that a heavier source of depression of wages for African-Americans seems to stem from "more integrated non-Hispanic occupations". All else equal, there appears to be a tendency for African-Americans to face an even greater wage penalty in more predominantly black occupations. These findings suggest that immigration policy and workforce development-related policies and initiatives may be relevant. Their interplay should be considered as part of the conversation to redress factors preventing occupational and wage mobility of minority individuals and groups in the labor market, such as the African-American workers and Mexican immigrants. 


\section{Endnotes}

${ }^{1}$ On the factor demand side, previous studies suggest that immigration can induce changes in production and industry structures that cushion its impact on natives' wages. For example, firms may absorb an increase in the supply of immigrants and adapt their technology to the local supply of different types of labor. Or, immigration can cause a change in the output mixed of local labor market, with labor-intensive industries expanding or moving to areas with large numbers of immigrants. Previous studies have found evidence of upward pressures on wages as a result of firms increasing their scale of production (and raising their demand in factor labor) to meet the increased demand for outputs by new immigrants (Altonji and Card 1991).Moreover, immigrants can add to the capital stock by bringing savings when they migrate as well as over time after their migration. In response to an immigrant influx, capital may also move across industries and areas, since unskilled labor may be more likely to serve as a substitute for capital (Hamermesh 1993). Since capital tends to be a complement to skilled labor and a substitute to unskilled labor, natives' wages in the skilled sectors would likely rise as a result of an influx of low-skilled immigrants.

${ }^{2}$ If factors of production are perfectly mobile, immigration will tend to exert no local effects-these effects would be entirely mediated through general equilibrium impacts on the larger market. This follows from trade theory; if economies are perfectly integrated, then local quantities are unrelated to local prices-the law of one world price for all factors will prevail. In other words, if one assumes that there is perfect factor price equalization (FPE) and no international factor price equalization, this means that immigration can affect aggregate wages but not relative wages across areas within a country.

3"New" Mexican immigrants for each census year: It is the count of the number of workers who are Mexicans and who immigrated after the last census year. So from the 2000 Census, the "new" immigrants are those who reported having migrated after 1990 up to 2000. From the 1990 Census, the "new" immigrants are those who reported having migrated after 1980 up to 1990. From the 1980 Census, the "new" immigrants are those who reported having migrated after 1970 up to 1980.

${ }^{4}$ There have been significant changes in the classification of occupations between the 1990 and 2000 Censuses that warrant careful attention when making comparisons. The 1990 Census occupational codes are based on the 1980 Standard Occupational Classification (SOC) system in which occupations are organized hierarchically in terms of the skill level and the experience considered necessary for individuals engaged in the occupations. By contrast, the 2000 Census occupational codes are based on the 1998 SOC, which classifies occupations by "job families"-job families combine occupations where people involved work together regardless of their respective skill level (i.e., doctors, nurses, and nurse assistants are grouped together). In addition, the 1998 SOC has more professional and technical occupations due to advances in technology and shifts in service-oriented sectors of the economy. Some 1990 occupations have become obsolete and do not figure in the 1998 SOC. In addition, some occupations have been "upgraded" or "downgraded". For example, farm, ranch, and other agricultural managers are found in the major groups of management occupations in the 2000 Census whereas in 1990, they were listed under farming occupations. Without ensuring that occupational categories across Censuses are comparable, it is impossible to get an accurate measure involving change in the occupational classifications over the period. Peter B. Meyer and Anastasiya Osborne of the BLS converted Census occupation codes from 1970, 1980, 1990, and 2000 to 1990 
scheme, available at the University of Minnesota "IPUMS Project" (ipums@pop.umn.edu). This dataset is used in the empirical analysis.

${ }^{5}$ As noted in Card and Lewis (2005): Calculations by Borjas et al. (1991) suggest that the 1980 Census missed approximately $40 \%$ of unauthorized Mexican immigrants, leading to a $25 \%$ undercount in the overall Mexican immigrant population. Van Hook and Bean (1998) estimate a $30 \%$ undercount rate of unauthorized Mexicans in the 1990 Census and a $20 \%$ undercount of all Mexicans. Norwood et al. (2004) suggest that the 2000 Census was substantially more successful in counting unauthorized immigrants. They estimated an undercount rate for unauthorized immigrants on the order of $10 \%$, implying an undercount of total Mexican immigrants of $6-8 \%$.

${ }^{6}$ To proxy the socioeconomic status of a job, we compute a composite index of human capital requirement to assess the quantitative meaning (in terms of relative wages and skill level) of each occupation. This composite index is adapted from the methodology of Sicherman and Galor (1990), whereby we derive a score or an ordinal scale from regression analyses of wages and the human capital requirements of the job. Ranging from 0 to 100, the scores represent the human capital standing of a particular occupation in the universe of detailed occupations of all individuals in the labor force. The average score across all 475 occupations reported in the Census is 34.8 (non-Hispanic white males have an average score of 37).

${ }^{7}$ Autor et al. (2003) developed a measure of the task intensity index for each occupation. As explained by Autor et al., the source of the task index comes from the Dictionary of Occupational Titles (DOT) that periodically evaluates the tasks required for more than 12,000 detailed occupations. Autor et al. merged this information with the Census Occupation Codes and organized the occupations into five categories: (1) manual skills-eye, hand, and foot coordination (EHF); (2) finger dexterity (FINGER); (3) direction, control, and planning (DCP); (4) general education math (MATH); and (5) sets limits and tolerance (STS). EHF entails the "ability to move the hand and foot coordinately with each other and in accordance with visual stimuli". Each detailed occupation gets an index value for each task indication (EHF, FINGER, DCP, MATH, STS). EHF relates to "manual skillseye, hand, and foot coordination"; FINGER is "finger dexterity"; DCP is "direction, control, and planning"; MATH is "general education math"; and STS is "sets limits and tolerance". This variable gets a high value in occupations that demand physical precision. FINGER gets high values if the job requires intensive use of finger and hand dexterity (such as a truck driver). Occupations in management/white collar get low values for this variable. DCP can be viewed as a proxy for communication skills. Autor et al. described this variable as one which represents occupations in which individuals possess "adaptability to accepting responsibility for the direction, control, or planning of people and activities". Occupations in management where individuals exhibit non-routine language and interpersonal communication skills get high values for DCP and low values for FINGER, whereas blue-collar/laborer occupations get low values for DCP and high values for FINGER and EHF. The two others (MATH, STS) relate more specifically to cognitive skills or intellectual skills (therefore, we do not make use of them in this paper).We calculate TASK as the relative value of manual skills to communication skills for each occupation (the sum of EHF and FINGER over DCP).

${ }^{8}$ The procedure for conducting the $J$-test involves the following. First, we run the IV wage regression with robust standard error and then we retain the residuals. Second, we regress 
the residuals on the controls and instruments (without the robust option). Third, we test using $F$-test that the coefficients on the instruments are simultaneously equal to zero. The $J$ test is equal to the $F$-test * number of instruments. Comparing the $J$-statistic with chisquare distribution with (number of instruments-number of instrumented variables) degrees of freedom, if the $J$-statistics is smaller than the critical value, the hypothesis of exogeneity is accepted. From the $J$-test, a $P$ value which is less than 0.05 means that the null is rejected, and we would conclude that either one or both the instruments are endogenous.

${ }^{9}$ The model is adopted from models developed in gender occupation segregation studies (e.g., MacPherson and Hirsh 1995 and Baker and Fortin 1999) with refinement to account for endogeneity of occupational choice (Hansen and Wahlberg 2000). Such model is appropriate for several reasons. Features of gender occupation segregation parallels ethnic/racial occupation segregation in the USA. Notably, we have seen that minority ethnic groups such as the Hispanic immigrants (and African-Americans, for different reasons) tend to hold different jobs (like men and women do); minorities/Hispanics earn less in those jobs. In the gender wage gap literature, it has been found that the negative relation between wages and female proportion of an occupation is stronger among men than among women and that individual wages shift systematically with the gender composition of occupation. Some evidence suggests that such "wage penalty" associated with largely immigrant and brown-collar occupations may be experienced by Hispanics in some main immigrant-receiving metropolitan areas (Catanzarite 1998; Catanzarite 2002; Tienda 1998).

${ }^{10}$ The non-randomness of occupation selection is controlled for by estimating in the first stage a probit model of occupational choice. The parameters from the first-stage probit model are then used to form a selection correction, similar to the Heckman lambda procedure that is added to the wage regression equation in the second stage. The formal model is given as follows: Assuming that the choice of occupation is based on the degree of "Hispanicness" of the occupation, the probit approach captures threshold values as one moves though the occupational choice decision ( Hispanic dominated $=1$, not Hispanic dominated $=0$ ).

$$
\begin{aligned}
& \operatorname{HISP}^{*}{ }_{i j}=\gamma_{j} Z_{i j}+\eta_{i j} \\
& \operatorname{HISP}_{i j}=k \text { if } \mu_{k-1}<H I S P *_{i j}<\mu_{k}
\end{aligned}
$$

where $k=0,1 \ldots$ and $\mu_{k-1}<\mu_{k}$ and where

$$
\begin{array}{rr}
\lambda_{i j}=\quad & \phi\left(\mu_{k-1}-\gamma_{j} Z_{i j}\right)-\phi\left(\mu_{k}-\gamma_{j} Z_{i j}\right) \\
& \Phi\left(\mu_{k-1}-\gamma_{j} Z_{i j}\right)-\Phi\left(\mu_{k}-\gamma_{j} Z_{i j}\right) \\
\text { and } \quad \operatorname{Ln} W_{i j k}=\theta_{j+} \beta_{j k} X_{i j k}+\delta_{j} \lambda_{i j}+\varepsilon_{i j k} \\
\text { with } \quad \varepsilon_{i j k \text { i.i.d. } \sim N\left(0, \sigma^{2}\right)}{ }^{\sim} \eta_{i j} \text { i.i.d. } \sim N(0,1) \\
\\
\text { Corr }[\varepsilon, \eta]=\rho_{k j}
\end{array}
$$

where index $i$ denotes individuals, index $k$ denotes occupation, and subindex $j$ denotes Hispanic immigrant/nativity ( $j=h$ (Hispanic immigrants) or $j=n$ (native)). Further, $\phi$ and $\Phi$ are the standard normal probability density and distribution functions, respectively. $\mu \mathrm{s}$ are unknown parameters to be estimated jointly with the $\gamma \mathrm{s}$. It is further assumed that 
$\varepsilon$ and $\eta$ are correlated with correlation coefficient $\rho_{k j}$. This methodology requires the use of an instrumental variable that explains occupation choice, but not wages. Age is used as the instrument, following Hansen and Wahlberg (2000) who suggest that once control for actual work experience is included in the wage equation, age is not predicted to be a determinant of wages in the human capital framework. The significance of the selection terms suggest that the instrument may be valid.

\section{Appendix 1}

Table 7 Detailed occupations where "new" Mexican immigrants go to

\begin{tabular}{|c|c|c|}
\hline 1980 & 1990 & 2000 \\
\hline Construction laborers & $\begin{array}{l}\text { Miscellaneous agricultural } \\
\text { workers }\end{array}$ & Miscellaneous agricultural workers \\
\hline $\begin{array}{l}\text { Miscellaneous agricultural } \\
\text { workers }\end{array}$ & Chefs and head cooks & Production workers all other \\
\hline Chefs and head cooks & Construction laborers & Construction laborers \\
\hline Grounds maintenance workers & $\begin{array}{l}\text { Grounds maintenance } \\
\text { workers }\end{array}$ & $\begin{array}{l}\text { Electrical electronics and } \\
\text { electromechanical assemblers }\end{array}$ \\
\hline Carpenters & Production workers all other & Chefs and head cooks \\
\hline Dishwashers & $\begin{array}{l}\text { Electrical electronics and } \\
\text { electromechanical } \\
\text { assemblers }\end{array}$ & $\begin{array}{l}\text { Rail-track laying and maintenance } \\
\text { equipment operators }\end{array}$ \\
\hline $\begin{array}{l}\text { Painters, construction, } \\
\text { and maintenance }\end{array}$ & Dishwashers & Welding, soldering, and brazing workers \\
\hline Production workers all other & $\begin{array}{l}\text { Counter attendants, } \\
\text { cafeteria food concession, } \\
\text { and coffee shop }\end{array}$ & Dishwashers \\
\hline $\begin{array}{l}\text { Electrical electronics and } \\
\text { electromechanical assemblers }\end{array}$ & Carpenters & Grounds maintenance workers \\
\hline $\begin{array}{l}\text { Drywall installers, ceiling tile } \\
\text { installers, and tapers }\end{array}$ & $\begin{array}{l}\text { Janitors and building } \\
\text { cleaners }\end{array}$ & Carpenters \\
\hline Roofers & $\begin{array}{l}\text { Rail-track laying and } \\
\text { maintenance equipment } \\
\text { operators }\end{array}$ & $\begin{array}{l}\text { Counter attendants, cafeteria } \\
\text { food concession, and coffee shop }\end{array}$ \\
\hline Carpet floor and tile installers & $\begin{array}{l}\text { Painters, construction, and } \\
\text { maintenance }\end{array}$ & $\begin{array}{l}\text { First-line supervisors/managers } \\
\text { of production and operating workers }\end{array}$ \\
\hline Janitors and building cleaners & Sewing machine operators & Sewing machine operators \\
\hline $\begin{array}{l}\text { Counter attendants, cafeteria } \\
\text { food concession, and coffee } \\
\text { shop }\end{array}$ & Roofers & $\begin{array}{l}\text { Grinding, lapping, polishing, and buffing } \\
\text { machine tool setters, operators, and tenders }\end{array}$ \\
\hline $\begin{array}{l}\text { Rail-track laying and } \\
\text { maintenance equipment } \\
\text { operators }\end{array}$ & $\begin{array}{l}\text { Drywall installers, ceiling tile } \\
\text { installers, and tapers }\end{array}$ & Industrial truck and tractor operators \\
\hline $\begin{array}{l}\text { Rail-track laying and } \\
\text { maintenance equipment } \\
\text { operators }\end{array}$ & Waiters and waitresses & Packers and packagers, hand \\
\hline $\begin{array}{l}\text { Metalworkers and plastic workers } \\
\text { all other }\end{array}$ & $\begin{array}{l}\text { Driver/sales workers and } \\
\text { truck drivers }\end{array}$ & Painters, construction, and maintenance \\
\hline Waiters and waitresses & $\begin{array}{l}\text { Rail-track laying and } \\
\text { maintenance equipment } \\
\text { operators }\end{array}$ & Driver/sales workers and truck drivers \\
\hline $\begin{array}{l}\text { Automotive service technicians } \\
\text { and mechanics }\end{array}$ & $\begin{array}{l}\text { Driver/sales workers and } \\
\text { truck drivers }\end{array}$ & Janitors and building cleaners \\
\hline
\end{tabular}

Source: 1980, 1990, 2000 US Census, PUMS, 5 \% sample 


\section{Appendix 2}

Table 8 The impact of Mexican immigration on wages dependent variable: log hourly wage individual-level analysis: OLS

\begin{tabular}{|c|c|c|c|c|c|}
\hline & $\begin{array}{l}\text { Pooled } \\
\text { sample }\end{array}$ & $\begin{array}{l}\text { Less than high } \\
\text { school }\end{array}$ & $\begin{array}{l}\text { High school } \\
\text { dropouts }\end{array}$ & High school & College \\
\hline $\begin{array}{l}\text { Mexican occupation } \\
\text { concentration }\end{array}$ & $\begin{array}{l}-0.034^{* * *} \\
(0.008)\end{array}$ & $-0.024^{* * *}(0.004)$ & $-0.016^{* * *}(0.004)$ & $\begin{array}{l}-0.03^{* * *} \\
(0.006)\end{array}$ & $\begin{array}{l}-0.066^{* * *} \\
(0.014)\end{array}$ \\
\hline Age & $\begin{array}{l}0.080^{* * *} \\
(0.005)\end{array}$ & $0.011^{*}(0.006)$ & $0.056^{* * *}(0.005)$ & $\begin{array}{l}0.055^{* * *} \\
(0.003)\end{array}$ & $0.13^{* * *}(0.008)$ \\
\hline Experience & $\begin{array}{l}-0.008^{*} \\
(0.005)\end{array}$ & $0.051^{* * *}(0.013)$ & $0.003(0.006)$ & & $-0.054^{* * *}(0.008)$ \\
\hline Experience ${ }^{*} 2 / 100$ & $\begin{array}{l}-0.220^{* * *} \\
(0.011)\end{array}$ & $-0.14^{* * *}(0.050)$ & $-0.159^{* * *}(0.018)$ & $\begin{array}{l}-0.144^{* * *} \\
(0.014)\end{array}$ & $\begin{array}{l}-0.247^{* * *} \\
(0.013)\end{array}$ \\
\hline Experience*3/1000 & $\begin{array}{l}0.024^{* * *} \\
(0.001)\end{array}$ & $0.012^{* *}(0.005)$ & $0.016^{* * *}(0.002)$ & $\begin{array}{l}0.014^{* * *} \\
(0.002)\end{array}$ & $0.027^{* * *}(0.001)$ \\
\hline Bachelor degree & $0.019(0.164)$ & & & & \\
\hline Post bachelor & $\begin{array}{l}0.164^{* * *} \\
(0.033)\end{array}$ & & & & \\
\hline Married & $\begin{array}{l}0.149^{* * *} \\
(0.007)\end{array}$ & $0.123^{* * *}(0.016)$ & $0.134^{* * *}(0.010)$ & $\begin{array}{l}0.16^{* * * *} \\
(0.009)\end{array}$ & $0.145^{* * *}(0.009)$ \\
\hline Constant & $\begin{array}{l}0.396^{* * *} \\
(0.083)\end{array}$ & $0.052 * *(0.191)$ & $0.729 * * *(0.069)$ & $\begin{array}{l}0.829 * * * \\
(0.062)\end{array}$ & $\begin{array}{l}-0.496^{* * *} \\
(0.149)\end{array}$ \\
\hline$R^{2}$ & 0.1885 & 0.0969 & 0.1232 & 0.1172 & 0.189 \\
\hline Number of obs. & 232,523 & 9413 & 36,011 & 78,505 & 89,774 \\
\hline
\end{tabular}

Robust standard errors in parenthesis. Regression disturbance terms are clustered at the occupation level. A state of residence fixed effects is included in all the specifications, coefficients not reported. Regressions are run for black males with positive earnings, born in the USA, aged 18 to 64

*Significantly different from zero at $90 \%$ confidence; ** significantly different from zero at $95 \%$ confidence; *** significantly different from zero at $99 \%$ confidence

\section{Competing interests}

The IZA Journal of Migration is committed to the IZA Guiding Principles of Research Integrity. The author declares that she has observed these principles.

\section{Acknowledgements}

I would like to thank Gady Barlevy, Jeff Campbell, and seminar participants at the Federal Reserve Bank of Chicago for insighful comments and suggestions on an earlier draft. I would like to thank Giovanni Peri and participants at the Worshop on New Frontiers of Immigration Research, organized by the Journal of Regional Sciences, held at the Federal Reserve Bank of Chicago on Nov 7-8, 2011, for helpful comments on an earlier draft. I am grateful to David Autor for providing me with the data to develop the instrument used for this study, and to Phil Doctor for valuable research assistance on an earlier draft. I would also like to thank the anonymous referee and the editor for the helpful comments.

The views expressed are the author's, and they do not necessarily represent those of the Federal Reserve Bank of Chicago or the Board of Governors of the Federal Reserve System.

Responsible editor: Denis Fougère

Received: 20 January 2016 Accepted: 6 April 2016

Published online: 26 July 2016

References

Adams C, Bartel D, Goldstein I, Kleniewski N, Yancey W. Economic erosion and the growth of inequality. In: Neighborhoods, division, and conflict in a ostindustrial city. Philadelphia: Temple University Press; 1991. p. 30-65.

Aldrich HJ, Carter T, Jones T, McEvoy D, Velleman P. Ethnic residential concentration and the protected market hypothesis. Social Forces. 1985;63:996-1009.

Altonji JC, Card D. The effects of immigration on the labor market outcomes of less-skilled natives. In: Abowd JM, Freeman RB, editors. Immigration, trade, and the labor market. Chicago: University of Chicago Press; 1991. p. 201-34.

Amitabh C. "Labor-market dropouts and the racial wage gap: 1940-1990", The American Economic Review, Vol. 90, No. 2, Papers and Proceedings of the One Hundred Twelfth Annual Meeting of the American Economic Association (May); 2000. p. 333-338.

Autor DH, Levy F, Murnane RJ. The skill content of recent technological change: an empirical exploration. Q J Econ. 2003;118(4):1279-333. 
Baker M, Fortin NM. Women's wages in the women's work: A U.S.-Canada comparison of the roles of union and public goods' sector jobs. American Economic Association Papers and Proceedings. 1999;89(2):198-223.

Betancur J, Cordova T, de los Angeles Torres M. Economic restructuring and the process of incorporation of Latinos into the Chicago economy, in Latinos in a Changing U.S. Economy, Comparative Perspectives on Growing Inequality, Rebecca Morales and Frank Bonilla, eds., Sage Series on Race and Ethnic Relations, v 7. 1993. California, USA: Sage Publications.

Bluestone R, Harrison B. The deindustrialization of America. Basic Books; 1982.

Blundell RW, Smith RJ. Estimation in a class of simultaneous equation limited dependent variable models. Rev Econ Stat. 1989;56:37-58.

Blundell RW, Smith R. Simultaneous microeconometric models with censored or qualitative dependent variables. In: Maddala GS, Rao CR, Vinod HD, editors. Handbook of Statistics, vol. 2. Amsterdam: North Holland Publishers; 1993. p. 1117-43.

Borjas GJ. Assimilation, changes in cohort quality, and the earnings of immigrants. Journal of Labor Economics; 1985. p. 463-489.

Borjas GJ. The economic analysis of immigration. In: Ashenfelter O, Card D, editors. Handbook of labor economics, vol. 3. Amsterdam: Elsevier; 1999. p. 1697-760.

Borjas GJ, Freeman RB, Lang I. Undocumented Mexican-born workers in the United States: how many, how permanent? In: Abowd JM, Freeman RB, editors. Immigration, trade, and the labor market. Chicago: University of Chicago Press; 1991. p. 77-1000.

Borjas GJ, Freeman RB, Katz LF. On the labor market impacts of immigration and trade. In: Borjas GJ, Freeman RB, editors. Immigration and the work force: economic consequences for the United States and source areas. Chicago: University of Chicago Press; 1992. p. 213-44.

Borjas GJ \& Katz LF. "The evolution of the Mexican-born workforce in the United States", NBER Working Papers 11281, National Bureau of Economic Research, Inc. 2005.

Borjas GJ, Grogger I \& HAnson GH. "Immigration and African-American employment opportunities: the response of wages, employment, and incarceration to labor supply shocks", NBER Working Papers 12518. California, USA: National Bureau of Economic Research, Inc. 2006.

Borjas GJ, Grogger J, Hanson GH. Imperfect substitution between immigrants and natives: a reappraisal, NBER Working Paper No. 13887. 2008

Butcher KF, Card D. Immigration and wages: evidence from the 1980's. Am Econ Rev. 1991;81(May):292-6.

Card D. Immigrant inflows, native outflows, and the local labor market impacts of higher immigration. J Labor Econ. 2001;19:22-64.

Card D. Is the new immigration really so bad? Berkeley: Department of Economics UC; 2005.

Card D, Lewis EG. The diffusion of Mexican immigrants during the 1990s: explanations and implications, NBER Working Paper 11552. 2005.

Card D. "The impact of the Mariel boatlift on the Miami labor market", Industrial and Labor Relations Review, ILR Review, ILR School. California, USA: Cornell University. 1990; vol. 43(2), p. 245-257, January.

Carrington W, de Lima P. Large-scale immigration and labor markets: an analysis of the retornados and their impact on Portugal. Ind Labor Relat Rev. 1996:49:330-47.

Catanzarite L. Immigrant Latino representation and earnings penalties in occupations. Research in Social Stratification and Mobility. 1998;16:147-179.

Catanzarite L. The dynamics of segregation and earnings in brown-collar occupations. Work and Occupation. 2002; 29(3):300-345.

Catanzarite L. Wage penalties in brown-collar occupations, Latino Policy \& Issues Brief, vol. 8. 2003.

Chiswick BR. Interpreting the coefficient of schooling in the human capital earnings function. World Bank Policy Research Working Paper 1790; 1997.

Chiswick BR, Miller PW. The endogeneity between language and earnings: international analyses. J Labor Econ. 1995; 13(2):246-88

Chiswick CU, Chiswick BR, Karras G. The impact of immigrants on the macroeconomy, Carnegie-Rochester Conference Series on Public Policy, vol. 37. 1992. p. 279-316.

Duleep H, Regets MC. The elusive concept of immigrant quality, IZA Discussion Paper, vol. 631. 2002.

Frey WH. Immigrants and human capital investment, AER Papers and Proceedings, vol. 89. 1995. p. 186-91.

Friedberg R. You can't take it with you? Immigrant assimilation and the portability of human capital. J Labor Econ. 2001;18(April):221-51.

Gallo C, Bailey TR. Social networks and skills-based immigration policy. In: Duleep HO, Wunnava PV, editors. Immigrants and immigration policy: individual skills, family ties, and group identities. Greenwich: JAI Press; 1996. p. 203-17.

Greenwood MJ, Hunt GL. The economic effects of immigrants on naive and foreign-born workers: complementarity, substitutability, and other channels of influence. South Econ J. 1995;61:1076-97.

Hamermesh D. Labor demand. Princeton: Princeton University Press; 1993.

Hansen J, Wahlberg R. Occupational gender composition and wages in Sweeden. IZA Discussion Paper 217; 2000.

Harrison B, Bluestone R. The great u-turn, corporate restructuring and the polarizing of America. Basic Books; 1988.

Hausman JA. Specification tests in econometrics. Econometrica. 1978;46:1251-71.

Hellerstein J, Neumark D. Workplace segregation in the United States: race, ethnicity, and skill. Rev Econ Stat. 2004;90(3):459-77.

Hunt J. The impact of the 1962 repatriates from Algeria on the French labor market. Ind Labor Relat Rev. 1992; 45:556-72.

Jibou M. Ethnic hegemony and the Japanese in California. American Sociological Review. 1988:53:353-367.

Johnson G. The impact of immigration on income distribution among minorities. In: Hamermesh DS, Bean FD, editors. Help or hindrance? The economic implications of immigration for African Americans. New York: Russell Sage Foundation; 1998. p. 17-50.

Kochhar R. Latino labor report, 2004: more jobs for new immigrants but at lower wages, Pew Hispanic Center Report. 2005. Kossoudji SA. English language ability and the labor market opportunities of Hispanic and East Asian immigrant men. J Labor Econ. 1998;6(2):205-28. 
Kosters MH, Ross M. The distribution of earnings and employment opportunities: A re-examination of the evidence. American Enterprise Institute Occational Papers; 1987.

Kritz MM, Gurak DT. The impact of immigration on the internal migration of natives and immigrants. Demography. 2001;38(February):133-45.

Lalonde RJ, Topel RH. Immigrants in the American labor market: quality, assimilation, and distributional effects. Am Econ Rev. 1991:81(2):297-302.

Lawrence RZ. Sectoral shifts and the size of the middle class. The Brookings Review; 1984. p. 3-11.

Lewis EG. Local open economies within the U.S.: how do industries respond to immigration? Federal Reserve Bank of Philadelphia Working Paper. 2003.

Macpherson DA, Hirsh BT. Wages and gender composition: Why do women's jobs pay less. Journal of Labor Economics. 1995;13(3):426-471.

Morris M, Bernhardt AD, Handcock MS. Economic inequality: New methods for new trends. American Sociological Review. 1994;9:205-209.

Mouw T. Social capital and finding a job: do contacts matter? Am Sociol Rev. 2003;68:868-98.

Neal DA. Why has black-white skill convergence stopped? In: NBER Working Papers Series no. 11090. Cambridge: National Bureau of Economic Research; 2005. http://papers.nber.org/papers/W11090

Norwood J et al. The 2000 Census: counting under adversity. Washington DC: National Academy of Sciences; 2004.

OECD (Organization for Economic Cooperation and Development). Global industrial restructuring. OECD's Business and Industry Policy Forums; 2002. https://www.oecd.org/sti/ind/1947035.pdf

Orrenius PM, Zavodny M. Does immigration affect wages? A look at occupation-level evidence. Federal Reserve Bank of Dallas Research Department Working Paper 0302. 2003.

Orrenius PM, Zavodny M. "Does immigration affect wages? A look at occupation-level evidence", Research Department Working Paper 0302. California, USA: Federal Reserve Bank of Dallas. 2006.

Ottavano G, Peri G. Rethinking the gains from immigration: theory and evidence from the U.S., NBER Working Paper 11672. 2005.

Park V. Access to work: the effects of spatial and social accessibility on unemployment for native-born black and immigrant women in Los Angeles. Econ Geogr. 2004;80(2):141-72.

Peri G, Sparber C. "Task specialization, immigration and wages", Centro Studi Luca d'Agliano Development Studies Working Paper No. 252. 2008. Available at SSRN: http://ssrn.com/abstract=1368863

Portes A, Bach R. Latin journey: Cuban and Mexican immigrants in the United States. University of California Press; 1985 Roy DA. Some thoughts on the distribution of earnings. Oxf Econ Pap. 1951;3(2):235-46.

Shoeni RF. New evidence on the economic progress of foreign-born men in the 1970s and 1980s. J Hum Resour. 1997:3(4):683-740

Sicherman N, Galor O. A theory of career mobility. J Polit Econ. 1990;98(1):169-92.

Terza JV, Basu A, Rathouz PJ. Two-stage residual inclusion estimation: addressing endogeneity in health econometric modeling. J Health Econ. 2009;27(3):531-43.

Tienda M. Immigration and native minority workers: Is there bad news after all? in: Help or hindrance? The economic implication of immigration for African-Americans. New York: Russell Sage Foundation; 1998. p. 345-352.

Toussaint-Comeau M. The occupational assimilation of Hispanic immigrants in the U.S.: evidence from panel data. Int Migr Rev. 2006;40(3):508-36

Toussaint-Comeau M. Ethnic social networks and self-employment of immigrant men in the US. East Econ J. 2012;38:74-98.

Toussaint-Comeau M, Smith T, Comeau Jr L. Occupational attainment and mobility of Hispanics in a changing economy, A Report to the Pew Hispanic Center. 2005.

Van Hook J, Bean FD. Estimating underenumeration among unauthorized Mexican migrants to the United States: applications of mortality analyses. In: Migration between Mexico and the United States. Research reports and background materials. Mexico City and Washington DC: Mexican Ministry of Foreign Affairs and U.S. Commission on Immigration Reform; 1998.

Von Lockette N D. Spriggs W E. Wage dynamcis and racial and ethnic occupational segregation among less-educated men in metropolitan labor markets. Review of Black Political Economy. 2015;43:35-56.

Waldinger R. Still the promised city? New immigrants and African-Americans in post industrial New York. Cambridge: Harvard University Press; 1996.

Waldinger R, Der-Martirosian C. The immigrant niches: pervasive, persistent, diverse. In: Waldinger R, editor. Strangers at the gate: new immigrants in urban America. Berkeley: University of California Press; 2001.

Wright R, Elllis M. Immigrants and the changing racial/ethnic division of labor in New York City, 1970-1990. Urban Geography. 1996;17:317-53.

Zhou M. Chinatown: The socioeconomic potential of an urban enclave. Philadelphia: Temple University Press; 1992.

Submit your manuscript to a SpringerOpen ${ }^{\circ}$ journal and benefit from:

- Convenient online submission

- Rigorous peer review

- Immediate publication on acceptance

- Open access: articles freely available online

- High visibility within the field

- Retaining the copyright to your article

Submit your next manuscript at $\boldsymbol{\sim}$ springeropen.com 